\title{
STUDY ON THE ARTICULATION TEST IN PRONUNCIATION IN SPEECH DISORDERS
}

\author{
By \\ G. FURUYA
From the Department of Oto-Rhino-Laryngology, Faculty of Medicine University of Tokyo. (Director: Prof. I. Kirikae)

In order to estimate the grade of speech disorders more objectively and quantitatively, the pronunciation test by means articulation scores were undertaken. According to the test method, degree of speech disorders was expressed quantitatively $(\%)$ by the number of syllables which were pronunced correctly.

From the study of 123 cases of speech disorders including stammering, otogenic stammering, nasal speech, cleft palate, cancer of the maxilla on which total resection had been done, cancer of the vocal cords, substitute voice and stammering due to disease of the nervous system, following results were obtained.

1) According to the test, speech disorders were divided into three groups according to the severity, the mild group ( $71 \sim 96 \%$ correct articulation in pronunciation), the moderate group (36 $\sim 70 \%$ ), and the severe group $(0 \sim 35 \%)$.

2) The correct articulation in pronunciation in various kind of speech disorders were examined and found as follows:-

(number of case)
7
12
10

Otogenic stammering

Nasal speech

(1) Rhinolalia aperta

(2) Rhinolalia clausa

Cleft palate

(1) Submucosal cleft palate

(2) Uranoschisis

(preoperative)

(postoperative)

(3) Uranopalatoschisis

(preoperative)

(postoperative)

(4) Cheilognatopalatoschisis

(postoperative)

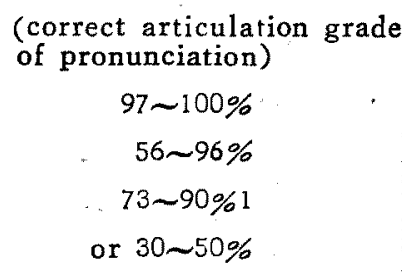

7

3

3

18

5

7

$$
\begin{array}{r}
41 \sim 59 \% \\
90 \sim 94 \% \\
47 \sim 72 \% \\
29 \sim 74 \% \\
33 \sim 75 \%
\end{array}
$$

$$
20-37 \%
$$$$
27 \sim 56 \%
$$

$24 \sim 78 \%$

Cancer of the unilateral maxilla after the total resection of the maxilla

5

(Prothesis or gauze pack was used)

$$
20 \sim 37 \%
$$

$82 \sim 88 \%$ 
Cancer of the unilateral vocal cord

9

Cancer of the larynx after total laryngectomy

(1) Esophageal speech

(2) Pharyngeal speech

(3) Pseudo-whispering

(4) Speech by Tapia's pipe

Neurosyphilis and cerebrospinal syphilis

Bulbar palsy

Others
$68 \sim 98 \%$

$$
\begin{aligned}
& 63 \sim 70 \% \\
& 49 \sim 67 \% \\
& 18 \sim 30 \% \\
& 43 \sim 73 \% \\
& 81 \sim 87 \% \\
& 15 \sim 97 \%
\end{aligned}
$$

3) Progress of healing, therapeutic effect of operation or cther treatment in above mentioned cases were presumed from comparison of the test results obtained at any intervals. Moreover, from observation of the disturbed syllables of pronunciation it was possible to find the location of lesion in articulation.

4) From observation by means of the test, author advocated a new concepts of "Upsilotismus", "Tpsilotismus" and "Nuzismus".

\section{言語障害の語音発語明暸度（語明度）に関する研究}

\section{果京大学医学部耳繁咽喉科学教室（主任：切替一郎教授）}

降年宾盛

目次

\section{I，緒論}

. II 研究方法並びに研究詨象

1) 研究方法

2) 研究対象

\section{III実験成績並びに唀按}

1）研究方法並びに研觉対象に対する検討
i) 原理
ii) 検查方法
iii）研究対像

2) 正常対像例

3) 㝘語笪害の程度

4) 溸晋障害 (雨)

5) 耳性榜音障害

6) 鼻声泟例

i) 開放性舆声

ii）閉空性悬声

7) 口盐 列

i) 炶膜下口蓋裂

ii) 軟口蓋裂

iii）軟硬口堛裂 iv）展顎口蓋裂

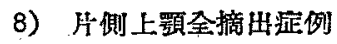

9) 声带癌

10) 知宣全摘出症例

i) 無喉頭音声症例

ii）人工姿頭法に上る泟例

11）神経系聟患に起因する稓語障害

IV 総括並びに結部

交献

\section{I 舶 論}

言語障害に関する探究は Hippokrates の古くから梁 い興味と大きな努力とをむつてすつめられ，逐次その学 問的体系を整光てきつなあるとはい光，小まだに科学的 な解明のゆきとどかない分野が少くない。

とくに言語の明瞭性の問題については，それが人間の 聴觉に大半を依存せざるを党ないことのため庴遍的 な全般に共通した客観的，数值的判定などの点に関して 必ずしも一般近代矣学见追随しうるとは言い得ない。

しかしながらこの主題を詳細に研究するに当つては，

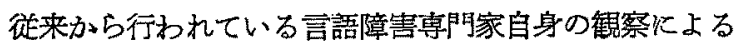
分折，固定とそれらつ粉括方法によらねばならぬ面が幾 
多存在することは勿論である.

現在まで言語障害以関する医学的領域炕和いて，その 発語明瞭度要数值的に比較観察するためのより客観的指 示標が存在しなかつた. 従つて言語障害の猃断の確定， 治潦方針の樹立をた怯その経過及び手術，之治療効果や治 㴰の判定，言語障害全般に共通しうる指示標に基ずいた 比較検討，あるいは会話能力における社会的適庝性に関 する推定，等々を客筧的数值的につかみ出すことができ なからたのである。

こょに括いて著者は始めてこの領域全般の臨床に新し

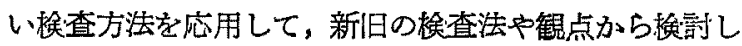
つ, 創ぬて言語障害全般のより客観的な数值的研究を 試み，新しい立場から観察し得た若干の知見について発 表し，本問題に関する諸賢の御批判を得たいと思う。

\section{II 研究方法並びに研究対象}

1)研究方法

i）検查法つ原理

最良受聴明膫度 $98 \%$ 以上の 正常聴力者が 被検者の発 音する「語音」を聴取して，被検者がが発音しようとし た「語音」と，実際に正常耳に德取された「語音」とを 比較し, 被梌者の言嘅能力を推定する。

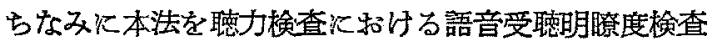
法 Speech Reception Test of the Hearing Acuity に対して 語音発語明瞭度 検查法（以下語明度洗と省略 する) Articulation Test in Pronunciation と呼 ふ5.

ii）検查方法

被検者は防音室内で絤查語表を一音節宛約 2 秒位の間 隔でよむ，その場合の声の強さは㭘者の耳るとで約 60 phone Kなるようにする。この被検者から $1 \mathrm{~m}$ 離れて 刘座した正常聴力を有する 5 人以上の検者によつて婹え たまつの語音が記録用紙仁記入される・この結果につい てつぎのような検討を試みる。

a) 語音発語明膫度值つ算出

被検者が発音しようとした語数に対して，正しく聴取 しえた語数の百分率（检者 1 人宛の結果については語明 度值と混同させないため特们用与る）を求め，各検者か ら得られた結果の中て最高值と最低值を除き，残りの中 間值を有する三人の各百分整值の算術平均をるつて被娭 者の語音発語明膫度とする。ちし小数点以下のあるとき は1位迄算出して4 搭5 万した。

b) 語音発語明湶底検查結果の分析

記録用紙に記大ざれた検查結果を，中間值を呈した

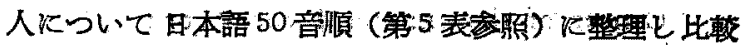
検討を加党る。これてよって弈害の範囲，たとえばどの 「行」とどの「列」が括かされているか，またはそれらの 代用語音つ検討や 3 人の検者のうち何人まで出異常聴取 したか，あるいはその先行子音炷とした障害があるの か，後続母音障害があるのかという各語音つ障害程度 等々の猃断を行う。

しかし実際問題として臨床上 5 人以上の正常渎力を有 する検者をその都度準備することについては種をの点か ら大きな制限が游わてくる.そこで著者性この一便法

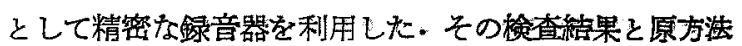
による結果との推計学的な比較検貄は考按で詳述する が，優秀な録音器であるならば充分信賴しうるるのであ st.

方法としては被検者によつて読まれた検查語音学一定 の規隻で録音し，この録音つ再生語音について後から語 音発語明瞭度検查法を適用するのである。

\section{iii) 検 查 音}

東京大学耳鼻咽喉科学教室の防音室を用いた。幅 12 $\mathrm{cm}$ の鉄筋コンクリート壁内に $3 \times 3 \times 3 \mathrm{~m}$ 大の部屋を 設置し， $1.5 \mathrm{~cm}$ のフェルト及びカルバス布 2 枚で厚さ $23 \mathrm{~cm}$ の防音壁によつてつくられた室である。

iv）桧查語表

第 1 表に示したよ5に日本語の清音 44 語, 濁音奻 半濁音 23 語と拗音つ 33 語の計 100 語音で，白本語々音 を殆どすべて含み，重復することなくしがあ必ず一回宛 で১くるようK at random に配列したるのである: 但

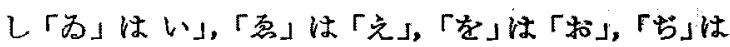
「じ」「ら゚」は「ず」と各々同一の語音とみなして取り 扱い重複をさけた。

これは全く意味を有しない1音節の語集であつて、こ れらの音節の組合せを 適宜に代えて，10 数ヶの検查語 表を準備し、検者及び被検者の慣れや予想期特の要素を 極力除くように努めた。

補註：書体は低学年呪童に読みかすいようひらかな とした。

v) 㭘 者

本検查方法の根本原理に基いて，検者は次の資格をる。 っことが要求される。

a) 自党的に德器に異常なく聴力検查の結果も正常で 峁り，その最良受聴明膫度が $98 \%$ 以上で，乙か子語音 受聴明瞪度嗾查方法を充分心理解しえたるのであるこ と. 
第1 表 梌 查器 $(\mathrm{No}, 1)$

\begin{tabular}{|c|c|c|c|c|c|c|c|c|c|c|}
\hline & 1 & 2 & 3 & 4 & 5 & 6 & 7 & 8 & 9 & 10 \\
\hline$I$ & ヘ & $3_{\infty}$ & 万 & す & 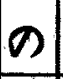 & $\mid \Xi^{0}$ & $t_{2}$ & せ & $t$ & $-f_{-\infty}^{\prime}$ \\
\hline II & す & お & 2 & 12 & $.3^{\circ}$ & $12^{\circ}$ & $t_{p}$ & 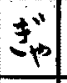 & $a$ & 5 \\
\hline III & 12 & $l_{2}$ & $z^{\prime \prime}$ & $u_{0}^{\circ}$ & $u_{0}^{\circ}$ & が & $\Xi$ & ぼ & t & 屯 \\
\hline $\mathbb{N}$ & 5 & $a^{\circ}$ & か & 50 & $\breve{p}_{p}^{\prime \prime}$ & だ & 3 & そ & $\mathbf{2}$ & 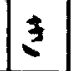 \\
\hline$\nabla$ & 胥 & $l_{\text {. }}$ & $\eta_{p}$ & $\left|\mathfrak{L}^{\prime}\right|$ & は & $\hbar$ & 27 & $L_{n}$ & ら & $\bar{\varepsilon}_{\hat{p}}$ \\
\hline$\nabla$ & $\dot{\imath}$ & $\mathcal{U}^{\prime \prime}$ & $<$ & l & $v_{1}$ & 9 & じ & $U_{x}$ & 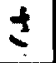 & め \\
\hline VII & $\phi$ & $U_{1}^{0}$ & & $\Xi$ & $\Xi$ & $l_{\infty}$ & 5 & $v_{2}$ & $\varepsilon^{\prime \prime}$ & 5 \\
\hline v & 2 & ほ & t & ぐ & $\eta_{2}$ & $1 \frac{1}{\phi}$ & 声 & ぜ & 15 & ば \\
\hline $\mathbb{X}$ & $\partial_{\hat{\phi}}$ & $1=$ & げ & $t=$ & L" & w & $2 \times$ & 2 & や & $c$ \\
\hline $\bar{X}$ & ざ & & $\eta_{10}$ & & $\xi_{\alpha}$ & & j & 3゙ & 6 & $1 \%$ \\
\hline
\end{tabular}

b）方言をるつていない中学生以上の年令㞗の人.

c）被検者の浐療にしばしば從事したり，被検者との 協同生活や交友等をしたことのない人，い小かえればそ の被検者の発音には甽れていないこと。

著者性主として東京大学々生の中から以上の条件をそ なえた模者を撰定して用いた。

\section{vi). 検查装置}

a) 録音器の綜合周波数特性

録音器は GT-6 型, No.8221, テーブューダー（東京 通信工業株式会社製)で，マイクロホンは同機に附属し たものを用いた。その狩性曲線は 50〜7,000c.p.s. Kわ たりほડ゙平坦であつた。

2) 研究対象

最近 5 年間代言語障害を主訴として東京大学耳鼻咽晱 科学教室言語障害部門を訪れた123名の患者で，その内

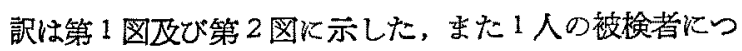
いては各々 1 万胵 9 回, 累計 1,000 余名の検者によって 300 余回の検查を施行した.

\section{III 実験成綘並びに考按}

1）研究方法並びに研究対象に刘する梌討

i) 原 理

言語障害について，その程度と障害されている語音の
第 1 図 全被検势の分類

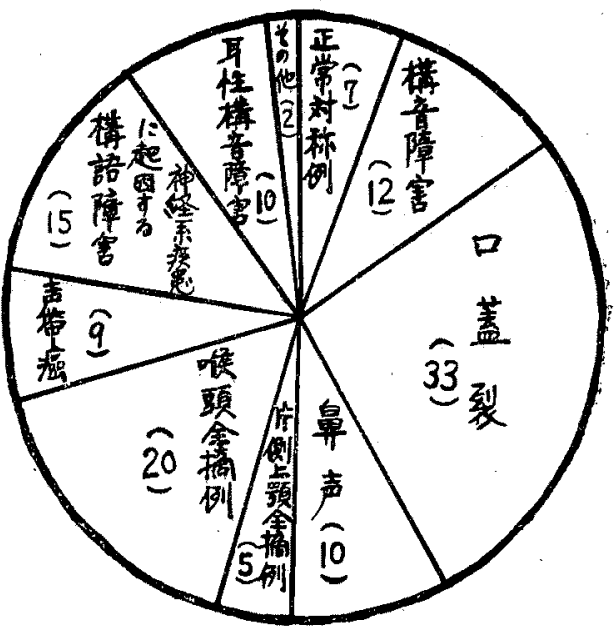

第2 图 全被検踷の年命䶁成

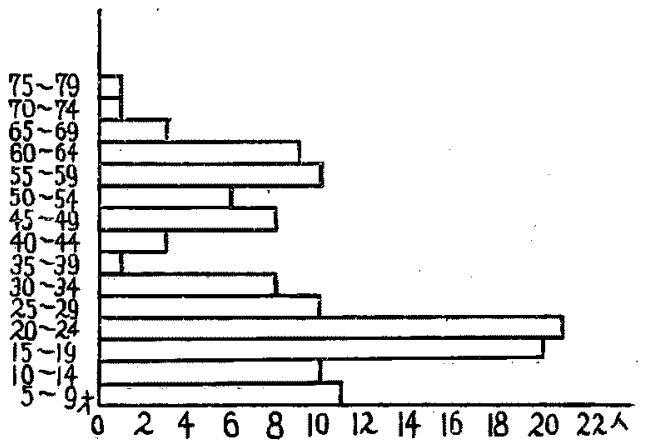

範囲を観察し，それに基いて障害機序を究明しようとす るのが目的である。

従来吾々は言語の明瞙性の判断に，検者が被検者の発 音を精渠に聴取してその異常を判定するといら検查方法 にたよつていたこのためには検者自身相当長期間の修 練と経䱃を必要とし，初心者にとつてはその普淈性とい う点で種ミの短所があつた・しかもその構音障害の程度 が他の言語障害と比較して表現される場合，それらの総 てに共通した概念の問题，あるいはとの明瞙性が社会的 会話生活からみてどの程度の支障をきたするのであるか そいら問題になると，これらの諸点関するより客観化 乃至はどこまで数值的に取り扱うことができるかという ようなことが要求されてくる.

また徉来よく習熟した検者自身は一般社会人が指摘し えないような詳細な診断が可能であつた反面，極力この 聴覚による判定からくる主観性をとり除くために意を用、 いていた.とくにある同一の疾患に長い間接している 
そ，そつ絓過に従つて変化する構音障害程变见客観性つ ある診断を適用することが困難となつてくる。事実本研 究においてる，この面に習熟した検者と一般社会人との 間には検查結果上に著しい美が見られたし，またこの点 諸研究者の等しく指摘するところである.

以上のようないろいろの短所と要求を完全㳘たして くれる診断法は言語障害に拈けるような感覚的要素の多 い分野に扣いては仲々見出し難いむのであるが，本法つ 原理はこれらの点関していさっか意を用いていると考 えられる。

しかし前述したように本法は正常耳によって被検者の 異常発音を判定しているのであるから，この点烺界が 生ずるのは当然つことであろう. 云いかえると本法にお

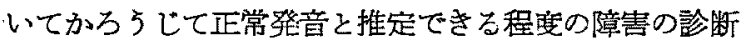
に閣しては，従来つ尃門的精密検査行またねばならない のである.この意味炕抌いてる本法はむくまで被検者の 日常生活に扣ける社会的言語能力の5ち主として明暸性 を検查するものであるとしなければならない。特に会話 能力の全般を正しく判定するためには，本泆以外嫦 の慣用語を検查語表としたところの会話率語音明膫度検 查やとの他ことばのアタセント,リズム，継続特間や声 の強さ，高さ，性質等のすべてを考慮すべきである。

ii) 検查方法

被検者が换查語表を 1 語音つ】読さ速さを 2 秒間隔に したのは，その間に険者つ全員が正確炕さえたま〉を 記録用紙書き込める余裕を与兄るためである・あまり 早いときには検者自身の慣れの問題や記憶力等その他不 要の条件が増して誤茩を大きくすることがある。

また検者の耳もとで約 60phone になるような声の強 ささ，曾通日常会話を行うときの大きさである・これは 岡本 (1951) によれば「正常耳の最良受聴明嗉度測定時 の音の強さとほざ一致し，しかもこの強さにおける正常 耳の受聴明瞭度の 分散は非常に狭く $\pm 3 \%$ 以下である」 といら．したがつて本法つ検查特拈いても正常耳を有 する検者全体の受聴明瞭医は士3\%以下の信頼限界であ ると考克て差しつか䒚ない。

この程度に一定した検查基準で結果を出しうるという ことは言語障害の診断法としてはまことに優れていると いわねばならないしかし言語障害者つ中にはこの声の 強さ澾し充ない疾患もありらる。と同時に 5 人以上の 検者が効座する必要上むあって，この両者間の距離を $1 \mathrm{~m}$ はなすことになり，強い嗄声を伴う疾患等ではこの 条件を充すことが困難になる。このような場合には声の
強さの影響を考慮すべきであるが，距離つ短縮等は他の 症例との比較検討や声量をむ加味した被険者の社会的会 話能力つ推定にも支障をきたすので，本法ておいては常 に $1 \mathrm{~m}$ の間隔を保つことつした.

被検者と検者との跑離を $1 \mathrm{~m}$ 汇することは Orthote lephonic System といわれているもつでああり，通信 通話の基本方式である・したがつてこの分野との検査結 果の比較便利である.

この際検者は被娭者厄対する読唇をさけることが必要 である・

a) 語音発語明瞭度值つ算出

検者が記録した結果を被裕者が読んだ䄼查語表と照し 合せて，正しく聴取し得た語数を各検者每に数えて百分 率值を出すのでするが，時炕被検者自身読みおとした音 節があるので，この場合は夷際に読んた語数坊対す正 常聴取語数の百分率を算出する.なお小数点以下は 1 位 迄計算して 4 捨 5 入した.

5 人以上つ検者つ各検查結果:の中て最高, 最低值のば らつきはそれらつ平均值に対して時に士10\%以上飞達 することひありうる.そこで各梌查結果か中で最高值と 最低值を除外し，そつ残らの中間值を呈した 3 人の結果 のばらつきにういてみると第3图つ如くに総数 264 回つ 中 $90 \%$ 迄が各平均値つ $\pm 5 \%$ 以内該当していた。 し かもそれ以上の場合極めて少く，最大士8％を出るこ とは臨床的に殆ど認められなくなつた. そつ上士5\%近 くなるるのはそれらの語明度值が $36 \%$ 以上 $70 \%$ の範团 内にある中等度言語障害の場合化多く，これ以外のるの

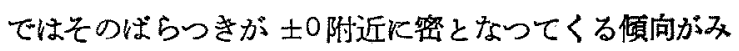
とめられた。

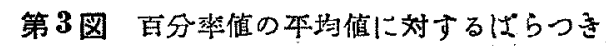

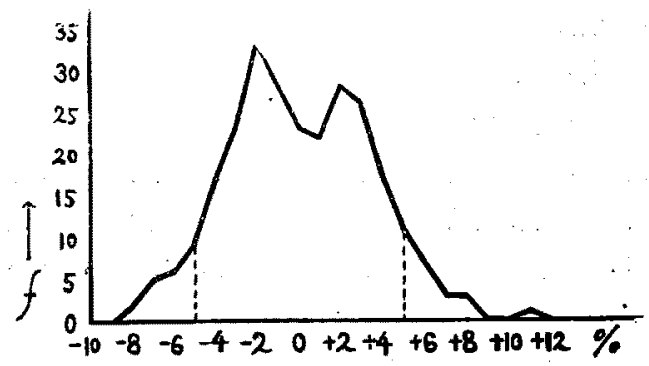

以上の結果から最高值と最低值を除いた 3 人の検者つ 百分率值の算術平均をむつてこの語音発語明瞭店值とす ると，そのばらつきが $\pm 5 \%$ 以内と考えて差しつかえが ない.な打小数点以下はこの場合す1位迄算出して 4唅 
$5 \pi L た$.

b) 語音発語明想度検查結果の分析 中間值を呈した 3 人の検查結果の中で，異常聴取した 語音を取り出して日本語 50 音表式に 整理してみると， をづ第一にどの行とどの列傽害語音が存在するかとい らことがはつきりする。この際各検者毎の結果を各闌仡 一定した順序で記入して和く々分析結果の比較検討に便 利であつて，より多くの正確な裏付を提供してくれるこ そゔある・たとえばどの検者はどの行の場合には一定し てどのような代用語音てなりやすいか，それら対する 正陮さの判断資すること等ができる．またこれら異常 聴取語音の結果を咨患別あるいは障害程度別に列挙表示 してみると代用語音の大体の傾向をつかむことができ る・たメ゙しこの場合の代用語音は本検查方法からみて当 然，一般にこのよ5な語音としてき〉とられやすいとい らこえを現わするのである。

さらにこれらつ異常聴取音を構音域つ立場から考察す ることもできる.すなから第 $1 ， 2 ， 3$ 構音域のいづれか に障害音がかたよっているようなことがないかどうかを 梌討するわけである・あるいはまたこれらをさら䛨細 にしらべるために構成器官，すなわら唇音，雨音，舌 音，口蓋音，咽頭音汇分けたり，ついで傋成音種，すな わら破裂音, 䶊音, 摩擦音, 流音, 半母音, 母音等につ いて観察することも有意義な結果をるたらするのであ る、またこの際無声子音，有声子音，抝音等についても 考擦してみる。

しかしながら以上の異常聴取音は言語障害専門医によ る判定ではないので，この結果もあくまで社会的な判定 の基碟つ上に成り立つているものであることを銘記しな ければならない。

つぎに異常聴取音が 1 人の検者のみの場合と，3人共 異常聴取している場合とがでてくるが，後者の場合の 方がその語音の障害程度が強いと見なすことができる。

一方日本語に括いては母音以外の各音節は子音部分々 母音部分の音素によって成り立つているが，この先行子 音炕障害つ主要因が存在するか，むるいは後綕母音迄る 異常聴取されているか火よつて，その語音刀障害程度を 数推することがでさる・たとえば本研究の対象になり光 た大部分つ症例で柱として，先行子音の部分が他の子 音こよつて代償されていたが，高度つ言語障害群の中に は後続母音要素までが完全こ異つた他つ母音要菜に異常 聴取されていた代用音声症例が見出されている。

また先㵔者 (1956) が原著として発表した「イ」列 構音障害例後述するような列（series）にその障害が

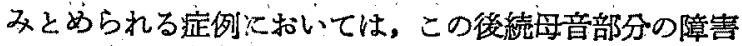
がみとめられることが多かつた。しかし軽度儿母音部分 の異常が存在するような埸合炕本法による診断では子 音部分つそれよりる不確実になりやすいるのである。

要するに異常聴取語音がそれに相当する正常語音とか けはなれている程との語音障害つ程度は高度である。た とえば先行子音も後続母音も共儿異常聴取された前述の 代用音声症例等は高度言語障害であり，その語明度す， 25\%であつた。

したがつて本法为 分析表柱棈竟障害刀「行」や「列上 の診断及び各語音つ障害程度等つ測定, 症状, 経過や治 療の指針，手術効果つ客観的な判定, ぞの語音から匡正 されてゆきやすいか，またはそれら障害つ治涳判断等に 資することができるが，その反面正常耳による感覚的判 定法であるから障害語音の歪みが少くてからうじてもと の語音として類推できる限りと括いては異常聴取音つ検 出は不可能である・このような場合には專門的な従来》 精密倹查による猃断法を併用すべきである。

c）語音発語明膫度検查方法に録音器を灾用した 場合の推計学的検討

本法に録音器を忘用して得られた語明度と，原法によ つて得られた語明度との間にいかなる差があるかという ことを吟味する・換言すれば録音器を用いた場合におけ る百分率值の原法化よる百分率值代対する信頼限界を求 めることになる。

（1）同一被検者について同一検者から得られた録音 器を用いたとき及び原法による場合の百分率值との差を 求める. 但しこの場合の $(+)(-)$ は録音器応用法に よる、百分率值から原法による百分率值を減じたときの符 号である.

$$
\text { 例: } \begin{aligned}
45 \%-41 \% & =+4 \% \\
64 \%-67 \% & =-3 \%
\end{aligned}
$$

（2）求められた值の度数分布表を作成する。

（3）この度数分布表より標本平均 $(\bar{x})$, 標本標淮偏, 美 (S)，不偏分散 ( $\left.\mathrm{u}^{2}\right)$ を求めると，

$$
\begin{aligned}
& \overline{\mathrm{x}}=\mathrm{x}_{0}+\mathrm{C} \sum \mathrm{af} / \sum \mathrm{f}=-2.81 \\
& \mathrm{~S}=\mathrm{C}\left(\sum \mathrm{a}^{2} \mathrm{f} / \mathrm{N}-\left(\sum \mathrm{af} / \mathrm{N}\right)^{2}\right\}^{1 / 2}=7.23 \\
& \mathrm{u}=\mathrm{S}(\mathrm{N} / \mathrm{N}-1) / 2=7.23
\end{aligned}
$$

（4）菓却积定を行う，すなは尚

$$
\overline{\mathrm{x}} \pm \mathrm{u}\{(\mathrm{N}+1) \mathrm{F} / \mathrm{N}\}^{\prime / t}=-2.81 \pm 14.45 \% \text {. }
$$

この範囲外の標本を除くＦ、 F 分布袁より危険率 5 \%で求めた. 
（5）漅却模定を行つた標本より度数分布表を作成す ると第 2表の如くなる。再びこの蓄から $\tilde{x}, \mathrm{~S}, \mathrm{u}$ を求 めると,

$$
\begin{aligned}
& \bar{x}=-2.23 \\
& S=5.21 \\
& u \doteq 5.21
\end{aligned}
$$

\begin{tabular}{|c|c|c|c|c|c|}
\hline 跸 䄲 $(\%$ & 陷粐值俥 & 数( & $a$ & $a f$ & $a^{2} f$ \\
\hline$-18 \sim-16$ & -17 & 1 & -6 & -6 & 36 \\
\hline$-15 \sim-13$ & -14 & 0 & -5 & 0 & 0 \\
\hline$-12 \sim-10$ & -11 & 11 & -4 & -44 & 176 \\
\hline$-9 \sim-7$ & -8 & 5 & -3 & -15 & 45 \\
\hline$-6 \sim-4$ & -5 & 14 & -2 & -28 & 56 \\
\hline$-3 \sim-1$ & -2 & 23 & -1 & -23 & 23 \\
\hline $0 \div 2$ & 7 & 23 & 0 & 0 & 0 \\
\hline $3 \sim 5$ & 4 & 4 & 1 & 4 & 4 \\
\hline $6 \sim 8$ & 7 & 8 & 2 & 16 & 32 \\
\hline 計 & & 89 & -18 & -96 & 372 \\
\hline
\end{tabular}

第 2 表 鹿数分布篦

（6） 母平均（m) の信頼限界の推定を行了：すなは b $\quad \overline{\mathrm{x}} \pm \mathrm{u}(\mathrm{F} / \mathrm{N})^{1 / 2}=-2.23 \pm 1.094 \%$

F はF 分布表上り危険率5\%で求めた。

以上によって録音器応用法炕上る百分率值の原法炕よ

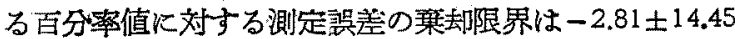
\%であり，同漾に録音器灾用による百分率值の原法によ る百分率值炕対する信頼限界はー2.23土1.094\%である。

したがつて臨床的火用いた語明度值はこれら百分率值 の3人についての平均であるかららこの両法に怙ける語 明度の差については特に考慮する必要はないと思われ る.このようにして録音器を本法応用することはそれ が佰透な録音器である限りに話いて推計学的に充分信頼 してよいと侾られる。

d) 検查語表

本検查語表は岡本 (1954) が発表した「語音受聴明蟟 度倹查用の語集に関する研究」の5ち無意 2 音節のロガ トームを1 音節表に代觉て応用したすのである。この研 究に扮いて岡本は「最良受聴明瞭度を求めるには1音節 法が適当である」そ結論している・本法に応用する場合 検者の最良受聴明瞭度の分散を極力慬少にするために無 意 1 音節表に代え，しかも語明度值の算出を便利にする ために 100 語音を採用したるのである。

また無意 1 音節の 100 語音を at random に配列した こと〉，この組合せを任意に代えて10 数式の語表を順 次交代に使用したことによつて被検者の発音に対する検
者自身の予想や慣れあるい性記憶等による誤差を除くの 飞役立てた。

\section{e) 検 者}

本法においいては特検者側飞慣れつ現象が強く現われ やずい。この慣れによる 語明度值の変動は土10\%程㡲 迄は臨床上文られるるので，当然この上らな結果は除外 されなければならない，各稀査間の結果のばらつきす少 くして語明度のより客観化とより一定した数值化とを計 る上にも前述したような条件 (II参照) が是非必要であ る.

iii) 研究刘象

対象中で特こIQ の正常值に澾しないものは除外す べきであり，本䃑究に括いてもこれを除外した．また学 令期以前は検查語表を読むことができないから対象とし て不適当である.

\section{2）正常対象例}

本法により言語障害者を検查すると先立ち，まずその 正常範囲を明確にして秥く必要がある。この目的のため 飞後述するような条件を具備した言語の正常刘称例を掇 定し, 累計 18 回の語音発語明貯崖検查を行つてみた. この撰定条件を挙げてみると，

1）新制高等学校卒業头上の年令と知能を有する健康 贸女.

2）方言むなく言語所芫正常であること。

3）既往症儿言語障害心関媇ある諸疾患のないこと等 が主な要点である。

これら 18 回の検查で各回の百分率值の最高と最低家 除外した非間值を，50名の検者力百分率についてみる と第 4 図の如くになつた.

すなから 97\%以上 $100 \%$ を示したものが50名中 48 名 (96\%) 相当している。岡本 (1956) は「語音か音 の強さが受聴者の耳もとで 60phone のときの正常耳の 受聴明瞭度の分散は非常沈㹨く $\pm 3 \%$ 以下である。した がつて 発語明瞭度検查 の場合も正常耳の 受聴明膫度は

第 4 図 正常都に対する百分率值の集計

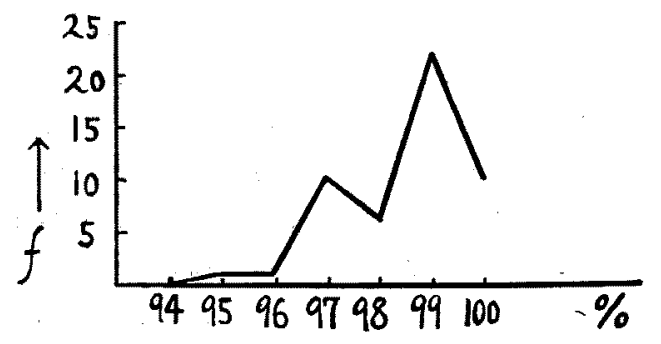


$\pm 3 \%$ 以下の信頼限界である」と発表している：これは 本研究にお゙いて臨床的に殆どすべての検者が $97 \%$ 以上 の百分繋を示していることと完全に一致している。

そこで正常者の語明度值はその誤茎を考慮に入れた上 で97\%以上100\%と考克るならば合理的であろ5と思 われる。

なお正常者の場合，いかなる語音が異常聴取されれす いかというとこれは各人によつて善があり一定した傾 向はみとめられないが，強いてあげるならば拗音である 3.その他唇音と鼻音が少しく異常聴取されやすい傾向 がみとめられた程度である。

つぎ火発語が正常な同一被険者に 2 回以上本法を反敛 した場合の語音発語明瞭度はどうなるかということにつ いては第了表の如くである。

その各回による分散は最下段の中等度言語障害つ代表

第 3 表 同一被㭘者に対する变動

\begin{tabular}{|c|c|c|c|c|c|}
\hline 例 回 & 1 & 2 & 3 & 4 & 平均 \\
\hline$I$ & $100 \%$ & $99 \%$ & $100 \%$ & $99 \%$ & $99.5 \%$ \\
\hline II & $99 \%$ & $99 \%$ & $100 \%$ & $98 \%$ & $99 \%$ \\
\hline III & $98 \%$ & $99 \%$ & $99 \%$ & & $98.7 \%$ \\
\hline$\pi$ & $97 \%$ & $99 \%$ & & & $98 \%$ \\
\hline V & $98 \%$ & $98 \%$ & & & $38 \%$ \\
\hline $7 I$ & $97 \%$ & $98 \%$ & & & $97.5 \%$ \\
\hline 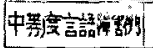 & $53 \%$ & $54 \%$ & $48 \%$ & $55 \%$ & $52.7 \%$ \\
\hline
\end{tabular}

例に比して非常に小さいことが理解できる。

3）言語障害の程度

各種言語障害つ程度を表現する力法としてつぎのよう な分類を試みた。

まづ各種程度の言語障害

総計 67 症例代対して一様につぎの如き事項に関する 問診調查及び診断を行った。

（1）初対面つ人との対談，電車汽車内でつ対談，電 話での対談.

（2）知人や家人との対談，麗事汽車内での対談，電 話での対談.

（3）口演（朗読），買物，註交，切符購入，换拶，呼 名その他用件.

（4）語音発語明臆度.

この際各項目別に極力具体的にど程度の支障を感じ ているか，被検者自身の訴えについて検討すると同時沉 また著者自身る言語の諸所見から積極的にこの点に関し て判定することに努力した．何故なら被検者自身の自覚 的判定つみに全てをたくするならば各症例により非常に 異つた程度の，しかも不確実な表現をするからである。

その上をた第，2）項の知人や家人との問題になると検 者及び被検者以外の第三者つ主観と慣れつ大きな要因が 加かり，著しく客顴性を欠くので，この項は参考程度に 留めた。

これらの諸条件の下に分類集計してみると第 4 表のよ らに一定した傾向がみとめられる・すなわち

第4表 言語㜔害の程 模

\begin{tabular}{|c|c|c|c|}
\hline & 程 & 度 & 全67 例中の語夏発語明睹度值 (\%) \\
\hline 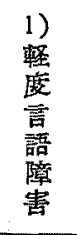 & 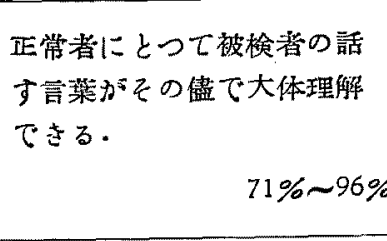 & 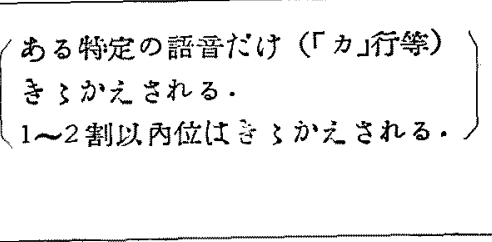 & 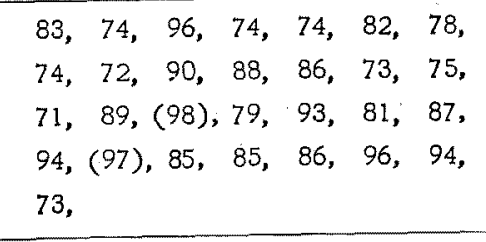 \\
\hline 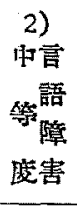 & 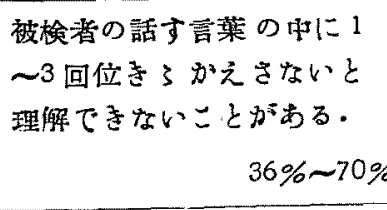 & 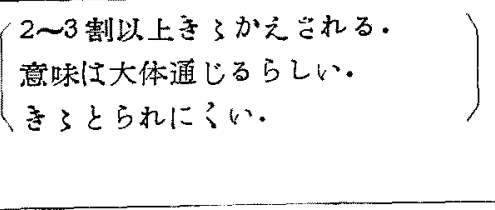 & $\begin{array}{lllllll}63, & 50,46, & 56, & 37, & 52, & (31), \\
43, & 51, & 47, & 58, & 38, & 43, & 55, \\
69, & 54, & 58, & 38, & 50, & 68, & 67, \\
(91), & 69, & 68, & 50,\end{array}$ \\
\hline $\begin{array}{l}\text { 3) } \\
\text { 高言 } \\
\text { 語 } \\
\text { 㜔 } \\
\text { 校害 }\end{array}$ & $\begin{array}{l}\text { 殆どなにを官つているのか } \\
\text { 理解できない. } \\
\text { 0\%〜35\% }\end{array}$ & $\begin{array}{l}\text { 通しがたい. } \\
\text { 全々かからぬ. } \\
\text { 筆話や讜展，手まれbする. }\end{array}$ & 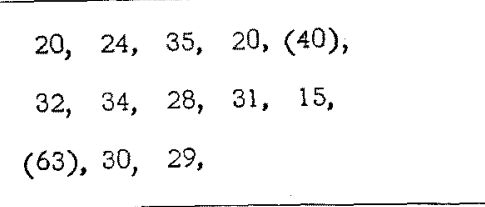 \\
\hline
\end{tabular}


(1) 軽度言語障害：71 96\%

(2) 中等退言語障害: 36 70\%

(3) 高度言語障害：0 35\%

に分類することができて，乙か子その日常会話能力に括 いてもその範囲が一定している。

（1）軽跤：被袷者つ言葉について特心注意をはらわ なくても大略理解できる。

（2）中等度：充分注意していないと理解できない。

（3）高度：充分注意していてもなにをいっているの か殆ど理解し得ない。

ぬたこれらの語明度值を各程度別にみると（1）及び （2）では大体平均して分散しているが，(3) では全列が その範囲の上位に集まつている。これは全然会話が不能 であるといち症例が少く，しかも外来に和ける検查とい 弓特殊性火よるものであろう。

つぎにこの分類方法による語明度值の 分布をその 300 回についてまとめてみると第 5 図つ如くである。秀お 等度が最多多く 133 回 $44 \%$,ついで軽度 ( $96 \%$ の 5 回 分が除かれているが）高底か順で，研究対象の程苃たよ る詳細が示されている・

第5图語曋発語明暸度值の分有

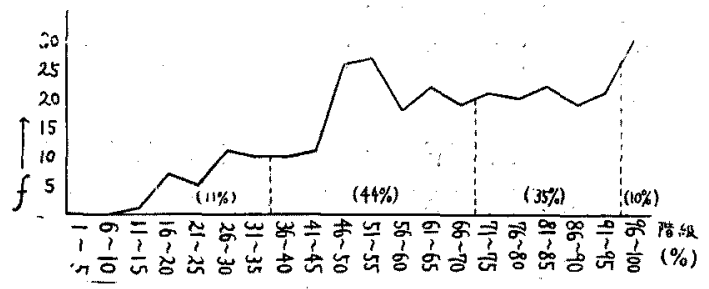

参照）及び神経系疾患に由来する構語障害 (11) 参照) を除いたつぎのよらな主をして散発性㻬について考察し てみた。

「カ」行丙 Kappazismus 4例

$\ulcorner カ ⿱ 上 小$ 行丙 Gammazismus 3 例

「サ」行内 Sigmatismus 4 例

「ザ」行两 Zetazismus 5 例

$\Gamma_{*} \perp$ 行丙 (Nuzismus) 1 例

「名」行丙 Deltazismus 3 例

$\Gamma, \perp$ 行徆 Rhotazismus 4 例

「公」行两 Betazismus 1 例

$\Gamma 1\lrcorner$ 列两 Iotazismus 3 例

「ウj列伭 (Upsilotismus) 2例

$\ulcorner\simeq 」$ 列柄 (Epsilotismus) 1 例

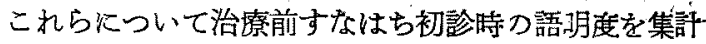
してみると、最低 $56 \%$ 最高 $96 \%$ の間にあつた。收等 度障害に属するのは 4 回のみでその他つ 10 回は軽競障 害相当していた.したがって㖞の外来診療に沶いては 主として軽度障害を対象としているといらことになる。 この中で $91 \%$ 以上を示した1例は歯間性「サ」行㖞 Sigmatismus interdentalis であつて, そつ各語音の 障害程度が少く本法によつては充分火検出し得なかった もので，従来つ尃門的構言模查を併用しなければならな からた。な执沉発性场をより多く対像とずれば当然語明 度はこれより低いう滵となる筈である。

語明故を1症例の絟過厄そつて追求してみると，第5 表つ如くにその执かされている「行」「列」の障害程度

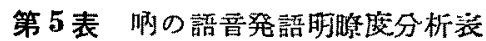

な括程度別分布における各最高の度数 はこの図表中箸少差ではあるが夫々その 範囲内での中央附近となつている。さて この分類において，いかなる疾患はどの

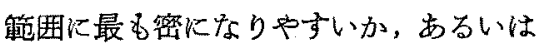
ある特定つ障害程蔗（例えば高度）では どのような語音が括かされやすいか， たは沶かされにくいか，等々の問題につ いては逐次气机らの疾患別考察してみ ることにする。

以上の諸点からみてこのような哣明度 值による障害程度の分類は合理的である と考える。

4）構音障墨（㖞）

この項では難聴に基く構音障害（5）

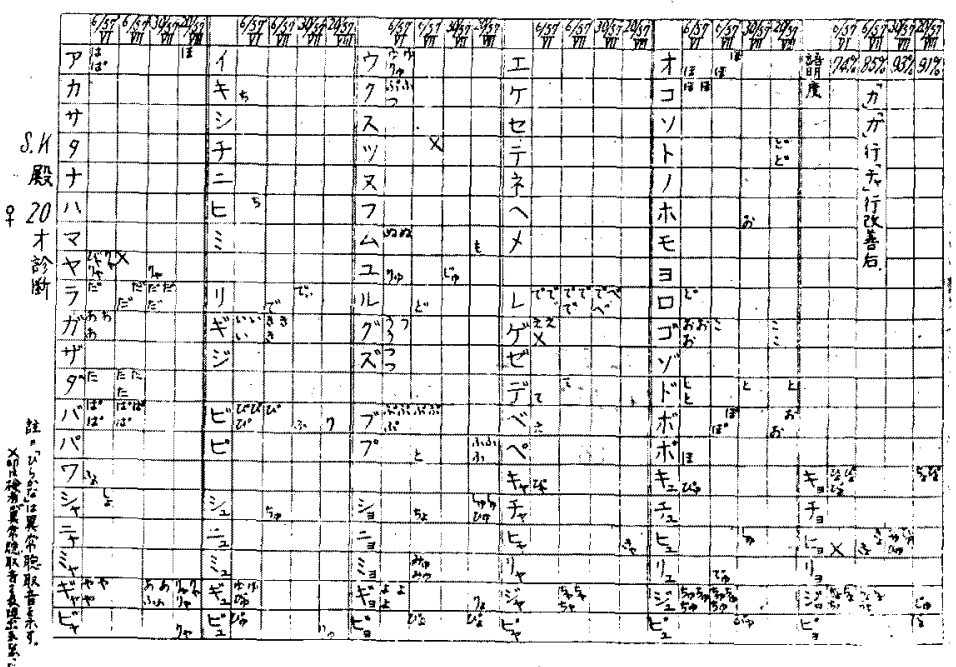




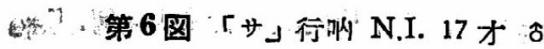

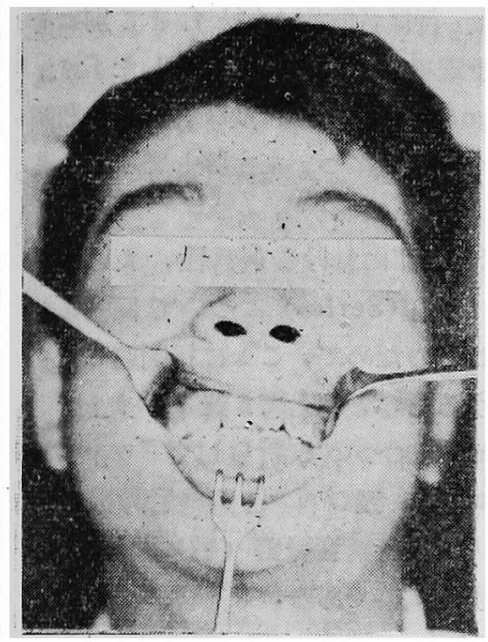

(32.10.22 撮影)

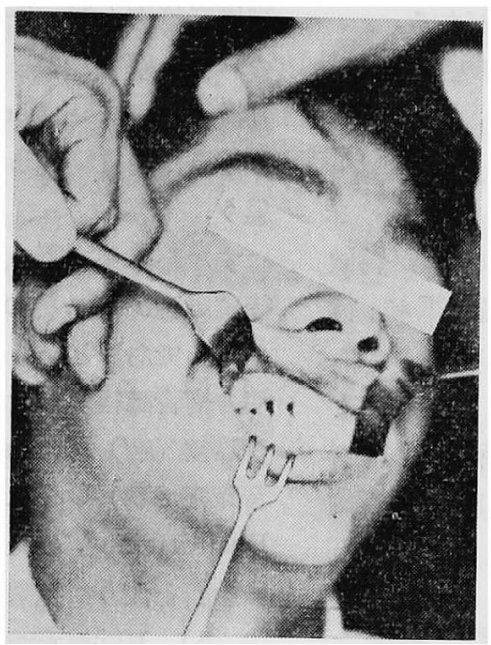

いては明確な一定性を見出し得なかつ た:

また全例について後続母音部分つ障害 は殆ど検出されなかつた・物かされた全 ての行, 列飞ついて先行子音つ障害つ多 かったことは母音呐 Vokale Stammeln を対象とし究なからたことからる当然で あろろし，またこの事は軽度障害つ分野 に和けるはつきりした一つの特徵でもあ る. しかし後述する2,3 の「列」の障害 にはこの後結母音部分つ障害がみられ る. この原因論については著者 (1956) が先に発表した「「ィ」列構音障曹 Iotazismus」を参照していたぶくことにし て，本検查の分析結果:から検出されたこ ととの代用語音等つ診断，初診特つ状態，症状，匡正さ 扣やすい語音とされにくい語音, 治療効果, 治瀿判定等 タが諒撂できる:

管 5 莣の左側闌外の診断名に外来診療の際の構音所見 飞よつてつけられたもつであるが，本検查分析表でもそ の結果と大略一致している.この点関して全例につい て集計してみると，構音所見から検出された 27 「行」 「列」中，このよらな分析裴からも一致して検出された ものは20「行」「列」であうた．しかもこれ以外抝音 の一致していたもつが 10「行」認められた。これら両方 の検查結果が一致していなからたるのは 1 症例つみでこ 机は前述した Sigmatismus interdentalis の例で, そ の歯列を第 6 図に示した.

これらの症例は診察をうける動機に「異常発音を他人 から指適された」ということが多く認められるが、この ような場合患者自身殆どそのことを自覚することなく， しかもその程变やそれらつ代用語音等関して自ら充分 飞納得していないことがある。このようなときに本検査 淫果について説明されるとよく納得できて，自身の治療 方針や治㴔判定て対して非常に合理的な結染をるたらす ことができるすのである.

つぎに分析表からそれらつ代用語音について教察して みると、「カ」行喻においては「ア」行によって代償され たものが 4 症例認められた，その他には後述する「ナ」 行㖞に「ガ」行によにて代用されていたるのがあつた が, これは著者が日耳鼻東京地方会第 27 回大会で 発表 した「ナ」行㖞（第 7 表）に和けるるのと一致してい :なな挌これ以外障害語音ととの代用語音つ関係につ
の「列」の障害症例について追加して持くこと〉する。

第: 6 表からは「サ」行,「ザ」行㖞以外以「列」(Series) に一連つ障害がみとめられている。とくに「ウ」列、「ェ」 列ついで「ィ」列にあらわれている・しかも三人の検者 共同様もしくは類似した異常聴取語音㹸っていること から，その語音つ障害程度は強い方である－各「列」に そつて後続母音刀障害がはつきり認められるが「ナ」行, 「ザ」行，「バ」行とそれらの行刀抝音すなわち「ニわ」

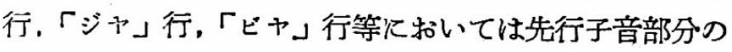

第 6 表「列」にみられる權音隚害

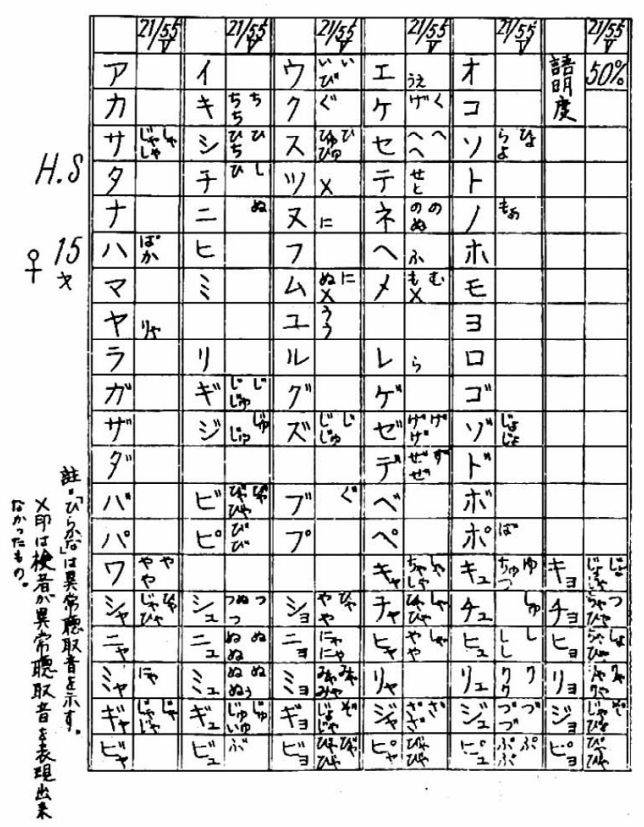


障寄が極めて少い所見を呈していることは日本語音の 「列」の特性から考台合せると興味樑いわのがある・

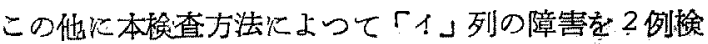
出することができた。

この装でもそうであるが一般に「ア」列，「す」列は5 母音と共に最る括かされにくい篹囲である。

第 7表は「ナ」行にその障書が双とめられる点が特徽 である.しかる前述した如く专の「ナ」行音性「ガ行 音で各代用されている。

以上の 4 症例に関連しては本邦では飯田，鈴木等によ る2，3の報告を見るにすぎないが，第 8 表の如く著者 (1955) が日耳悬東京地方会第 27 回大会で口演した症例

第 7 表 「ナ」 行时

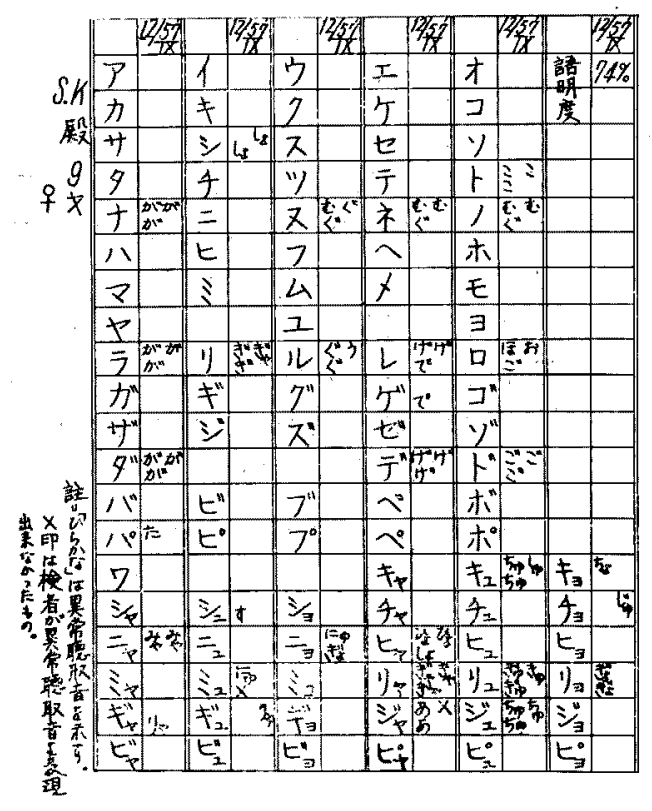

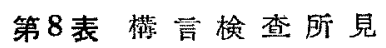

\begin{tabular}{|c|c|c|c|c|c|c|c|}
\hline 1 & 22 & & a & & $110=$ & $1227 \times b 78+$ & 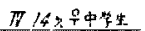 \\
\hline $\bar{p}$ & 1 & r & $I$ & $\pi$ & 171ウI才 & $717=才]$ & P17口A \\
\hline 力 & ₹ & 7 & 个 & ב & $n$ & カキクケコ & カ \\
\hline T & シ & $\vec{z}$ & 七 & y & & サシス七v & サシスヒり \\
\hline & \pm & $" y$ & $\dot{I}$ & $r$ & 8千 & $94 ッ \div+$ & {$[9+1 y+5$} \\
\hline & & $x$ & ネげ & $f=*$ & & $=x+$ & $t=x+1$ \\
\hline a & 七 & 7 & $a$ & 木 & & $7 \frown ホ$ & IE $72 \pi$ \\
\hline ₹ & \& & 么 & $x$ & $E$ & & $\nabla \leqslant \Delta / E$ & $\nabla \leqslant \Delta \not E$ \\
\hline$P$ & 1 & 1 & $I$ & $\exists$ & & $112=3$ & P 12 工 \\
\hline$\overline{7}$ & ) & ル & L & 口 & $\overline{7}$ & ラリルレロ & ラリルレ口 \\
\hline 7 & 1 & ウ & 工 & 7 & 7 & $71 ウ \pm 7$ & 7 1ウェ3 \\
\hline 2 & & & & & & & \\
\hline$m^{*}$ & ギ & $\gamma^{2}$ & $T^{*}$ & $\beth^{\prime \prime}$ & & & がギゲゲ \\
\hline ザ & 3 & $\pi^{\circ}$ & ヒ" & $y^{*}$ & & & t" \\
\hline$g^{*}$ & + & $w^{*}$ & $\tilde{T}^{\prime \prime}$ & F゙ & & チッ゙デ & バデト \\
\hline バ & E* & $7^{*}$ & $へ$ & ボ & |x́ & ビブべ利 & 7゙ベ \\
\hline バ & $E^{*}$ & 70 & 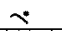 & 办 & & $\div 7$ & $7^{\circ}$ ベ \\
\hline
\end{tabular}

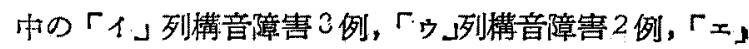

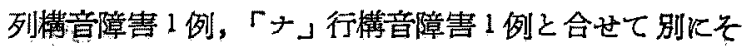
の詳細を原著とする予定であるが，先に発表した「イ」

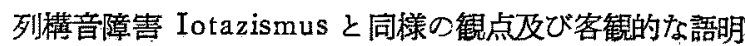
层検查法の立場からつきの点について主張してみたいと 思了.

すなわら日本語の50音節に扣ける特殊性，たとえば 後結母音方备々その「列」(Series) Kついて 同名類似 のものであるということのためにっこょに枳開連した一。

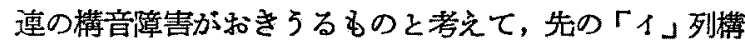

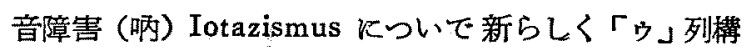
音障害 (㖞) Upsilotișmus 及び $「 ェ 」$ 列構音障害 (明) Epsilotismus,また「ナ」行構音障害（㖞）Nuzismus の診断を仮りに提唱する次第である.

5) 耳性構音障昌

桡音障害と聴力障害との間に存する臨床病理上の近代 科学的な関保については，今世紀になつてから Bloch (1907), E. Fröschels, u. F. Fremel (1914) 等加「内 耳性難聴と $\mathrm{S}$ 音障害との関係」について指摘して以来, H. Gutzmann, (1911), W. Köhler (1913), C. Stumpf (1921), L. Stein (1929), G.E. Arnold (1941) 等その 他多数の学者によつて解明されてきた。

我が国に和いてす田中（1913）によつて迷路性難聴が 湮因で「サ」を「゙っと発音する36才の農夫にりいて 発表されてから三宅 (1933) 西島 (1940) 等化よのて種 々教察されてきた。

しかしいつれもその障害語音について明暸性の面から 観察したものがないのでこさにそれらの点に閣して若 干の㭘討を試みた。

この項で対象とする症例はすべて感音系矱聴に属する むのである・すなわらそれらの聴力図は高調音急堅型で $1000 \mathrm{cps}$ 以上が $60 \mathrm{db}$ 以上括ちたものが 4例(第 1 群)， 全周波数にわたつて $60 \mathrm{db}$ 以上の高度難聴水平型艺呈し

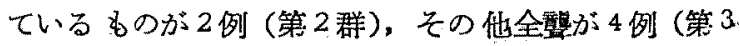
群）である. また骨導聴力は全症例共 $20 \mathrm{db}$ 无至 $30 \mathrm{db}$ 以上括ちており，Recuruitment 現象陽性も認められて いる.

まつ第一に言語登育過程に奶して如何なる时期とこれ ら感音系難聴が発来したか，本たこの発来時期の差によ つて語音発語朋筣度の上にどのような差をるたらすかに ついて検討してみることとする。

言語発育過程の一応の終了時期を 5 才（完全な終了時 期は10〜19才と，むるいは言語㽝得はれ才で完了する 
等といわれているが）とするならば，第9表の第 1) 行 K示すように，終了後すなわち本項では5１5 才に難聴 が発来した場合の語明度值は夫ネ 79，90，86，86，73，85，

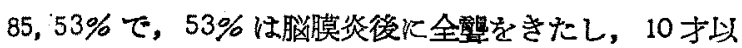
後知能の正常な発達むまた不玎能だつたと思われる症例 であった、これを除いた他の症例についてみると73〜 90\%の軽度言語障害に属し， しか子80\% 台相当して いるものが多かつた.

第 9 表 耳性 搆 豆障 害

\begin{tabular}{|c|c|c|c|c|c|c|c|c|c|c|}
\hline 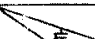 & & t & $\nexists$ & & 72 & 2群 & $\bar{t}$ & 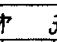 & $z^{\prime}$ & \\
\hline 智够 & I & II & III & $\pi$ & $\vec{V}$ & $\pi$ & mit & \begin{tabular}{|l|l|} 
nIn \\
\end{tabular} & $7 \pi$ & $\bar{x}$ \\
\hline 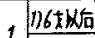 & 79 & 90 & & 86 & 73 & & 86 & 85 & 85 & 33 \\
\hline 7 25 妨前 & & & 50 & & & 30 & & & & \\
\hline$\frac{6}{63}$ & & & & & 73 & & & & & \\
\hline Tht & 79 & 90 & & 86 & & & 86 & 85 & 85 & \\
\hline 力 & \pm & & \pm & \pm & & + & & & + & \\
\hline サ 行 & + & + & + & $(+-)$ & & + & & (t) & & \\
\hline 标 & \pm & \pm & \pm & \pm & & + & & $(t)$ & & \\
\hline 儿行 & \pm & \pm & \pm & & & + & & & & \\
\hline 5 行 & \pm & + & \pm & & + & + & & \pm & & \\
\hline ガ 行 & + & & \pm & \pm & & +1 & & \pm & & + \\
\hline ザ 行 & + & + & + & $(+1)$ & \pm & +1 & & & & \\
\hline $\begin{array}{lll}g^{\prime \prime} & \text { 行 }\end{array}$ & & & \pm & $( \pm)$ & & + & & & & \\
\hline$\sum_{\uparrow}$ 行 & + & \pm & + & & & + & & & & $f$ \\
\hline E+ 行 & & \pm & + & \pm & + & +1 & & & & + \\
\hline$\ddot{j}_{\uparrow}$ 行 & \pm & + & $T$ & & & +1 & & \pm & & \\
\hline$E_{+}+$行 & + & & \pm & \pm & & +1 & & & & \\
\hline 关他 & 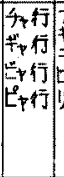 & 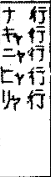 & 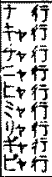 & 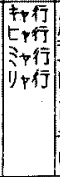 & 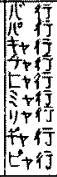 & 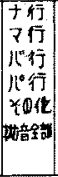 & 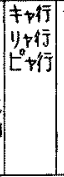 & 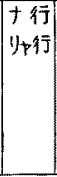 & 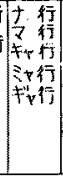 & 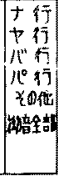 \\
\hline
\end{tabular}

つぎに終了しない前にすすなはち本項においては共に 1才 (言語習得開始前に相当する) で難聴が 発来した場 合は第9表の第 2) 行目に示すよ5に50,30\% で中等 睡乃至高度言語障害で、前者よりその障害程廉は強いる のであつた.

難聴の程度と語音発語明睽度との関係についてみると 第 9 表のよ5に，第 1 群の高調音念陮型と策 2 群の高度

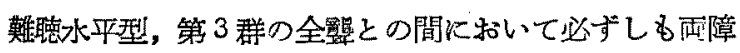

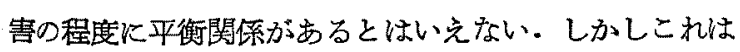
対象例数の少いことに起因しているのかもしれない：さ らにまた言語発育過程が一応終了した後に括ける難聴の 経過期間との関係で，この項に括いては 4 才以下で難 聴の発来した症例 III， VI を除いた他の全例について第9 表の第 3）行と第 4) 行で比較してみると，難聴が発来 して 5 年以下の開に語音発語明瞭度梌查をうけたるの
と，10 年以上たつてから梌査されたものとの間には例 数の少いためか説明しやすいような関保を見出すことが できない。

勿論生活年令による差るみとめられない，

以上要するに難聴が椿音障害に及洨す影響について は，難聴の程交，檑類，性質むるい㤔の感覚器の状態 や注意力等々その他の多くの票因を洘慮すべきことは勿 論であるが，その難聴発現時期のみについて云らなら ば，言語習得前に発来した方が習得後に発来した場合上 りる大きいと考えられる.この主要因としては正しい言 語機能の発育過程に重要な役割を分坦している感覚性並 びに，運動性言語中枢における夫ふ言語音響像(Wortklangbild) 々言語運動像 (Wortbewegungsbild) の形 成すなわち内的言語の形成と，それに伴５正しい構音 作用の習得に大きな支障をむたらすためであると考えら れる.この点関して G.E. Arnold (1941) は「言語 障害つ程庤は難㯖発来力時期炕関保し, Kleinkinder の 時期に難聴があると構音障害は自然僧悪してゆき，成 人になつてからの耳笑患ではそれが高度難㯖に達する頃 には Sigmatismus のみが朋らかとなる」と述べている が，著者の結果はこれを数值的に表示している.

しかしながら難聴を合併した構音障害の程度を語明度 の立場からみる場合には，難聴であるといら大さな要因 を充分に教虑した上で取り扱ら注意が必要で劣る。

第 9 表の第 2 群及び第 3 群すなわら高聂聴力障害水平

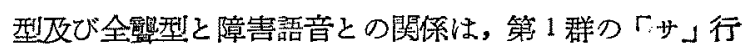
等に誌められるような全症例供通した所見が少い。こ れはそれらの聴力障害と特定つ語音つ障害との関俰より も，その聴力障害型からみてもより広筑围なしかも不 特定の語音汇影響を及伎すことが多いのではないかと思 われる所見である・すなわら第 2 群つ症例化第 3 群の 症例Xとに括いては, 殆ど全ての語音に障害がみとめら れていることなどである。

これら聴力障害泭随して，多くの構音器官の二次的 な機能不全そ生ずるためもむるのであるらが，その他の 従来知られていなからたよな聴覚々需語との相互関俰 が存在して起きてくるものであるかもしれない.これら の点関しては将来臨床病理上の研究, あるいは Sonagraph による研究などに大きな期待がかけられる.

第 10 表は高調音急隥型聴力障害を 呈した 耳性構音障 害つ代表的語明度分析表である。

障害語音つ「行」についてみると第9表にも整理した 如く、「サ」行，「ザ」行及び怣音つ「シヤ」行，「ジけ」 
第 10 表 耳性「サ」行啊

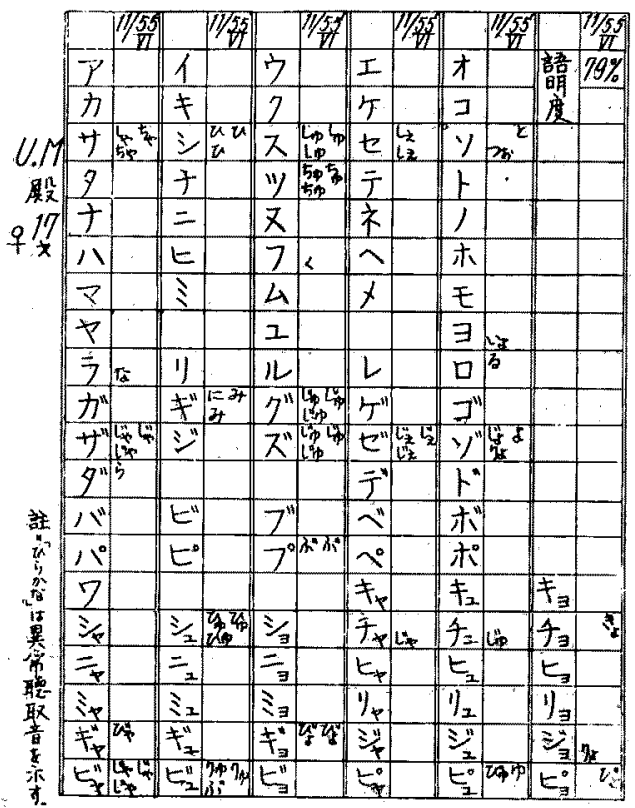

行が最多くっついで「カ」行、「タ」行、「八」行、「ラ」 行「が」行，之抝音刀「ビヤ」行が和かされている。

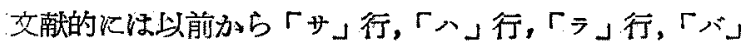
行「バ」行等方指摘されている。

な招代用語音比しては Bloch（1907）は「内耳性 難聴者について $\mathrm{S}$ 音つ代りに $\mathrm{T}$ 音を発音する」とい つているが，W. Köhler（1913）は内耳性難聴者に何故 $\mathrm{S}$ 音が特に障害されるかということに対して実験心理学 的に「「ガルトン氏笛の $\mathrm{C}^{0}$ 以上の音は $\mathrm{S}$ 音に似，特こ 8400 振動数の時ォブチマールで, 更に 振動数が 增すと $\mathrm{S}$ は F の性質を物びてき，17,000 亿達して純粋の F となる. 倚振動数が増すと $\mathrm{Ch}$ を発する，従つて若し $\mathrm{C}^{5}$ 以上飞欠宿があるときは $\mathrm{S}$ 音の感受は消失する管 である」と証明した。すなわち高調音急墜型の聴力障害 を伴つた本項の第 1 群 4 例に执いては，語明度分析上 「サ」行が「八行顶至拗音の「シャ」行に，「八」行 が「サ」行に，「ザ」行性揞の「ジヤ」行に異常聴取 されたが，その他の語音については一定の洗則を見出し 得なからた。

また後続母音部分よりも先行子音の障害つ方が強く， 全症例について後綕母音の翼常聴取は殆ど認められなか つた.

つぎに最良語音受聴明瞭度、と語音発語明膫度との関係 にっいてみると，症例Iに括いては前者 $41 \%$ ，後者は
第11表 分析表方比較

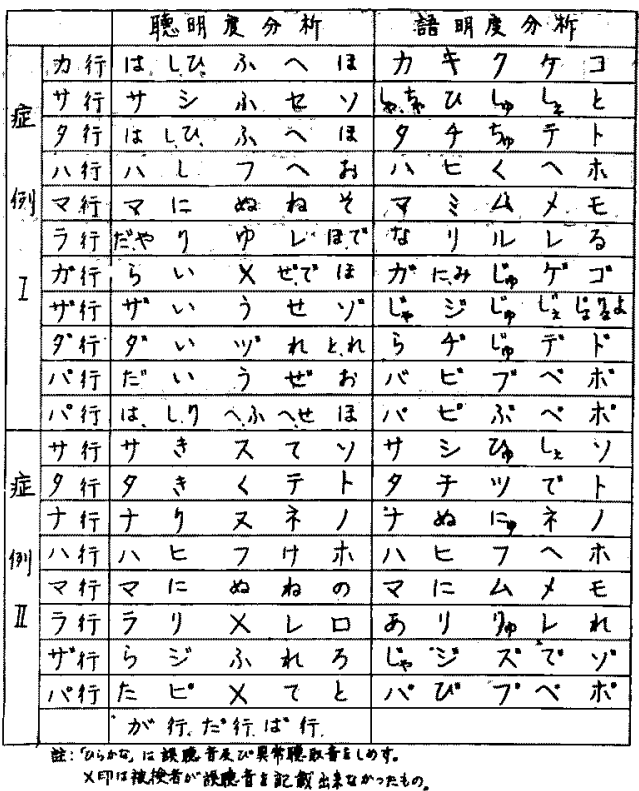

$71 \%$ で，症例 I 飞特いては前者が 00\%で後者は90\% と なつており，語音受聴明瞭莨の 障害範围の 方が広から た。

ついで最良語音受聴明瞭度検査結果を 50 音表式に 整 理してみると第11表の症例に和いては「カ」行,「タ」 行, 「マ」行, 「ラ」行, 「が」行, 「ザ」行, 「ダ」行, 「バ行「パ」行についで「少行と「八」行にその 障害がみられ，同症例の語音発語明膜度分析表に見られ る異常聴取音と比較すると「サ」行,「が」行，「ザ」行 と「カ」行「タ」行，「パ」行等が一致している。しか し前者の誤聴語音つ方が広い箦围侵されている。なお 與味深いことは「カ」行，「サ」行と「タ」行をこれら よりも高い振動数を有する「八」行音として器聴し，一 方「サ」行等をより鋭い「シャ」行音に近く異常発音し ていることである。

同様に症例公については「サ」行，「タ」行，「ナ」 行,「マ」行,「ラ」行, 「ザ」行, 「パ」行比いて雨者 の一致をみたが語音受聴明蹽度検查つ障害語音の方が広 い籍囲にわたつていた。な打「サ」行と「タ」行を「か」 行として謖聴し、自らは「サ」行を「八」行乃至「シヤ」 行で代用している，以上両症例火共通している点はサ」 行,「タ」行,「八」行と「シ」行及び有声子音つ大部分 を諮㯰したり，異常発音したりしていることであるが， 「マ」行を共に「ナ」行音として誤聴しているのは今後 検討要要する所見である。 
また症例 Iは日常生活に和いて他人の会話を聴取する

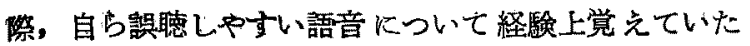
が，この自覚している誤聴語音と語音発語明湶烧の分析 表から得られた黑常聴取語音との関係は, 前者の方が広 範囲沈わたつて拉り，後者は大部分前者の範围内に含ま れており，しかも「サ」行や「」行等で大略一致して いた.

症例】は初診後満 2 年経過しているが，いまだに「邓」 と「シュ」等つ区別がはつきりしないと訴光，自ら「ス」 を発音しているつもりでも「シュ」と他人にはきかれる ことがあることを認めている。こ我は特そらく内的言語

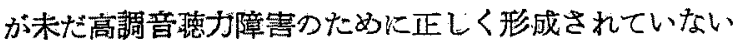
か、いわゆる Akustische Kontrolle ができないため がよるものと思われる。

このように患者自身の誤聴語音あるいは自覚誤聴語音 と，患者の発音沦刘しての異常聴取語音との関倸はある 特定な範囲に洛いては認めら机るるので，特儿「サ」行 と拐音の「シャ」行沉密接な右関連性が存在するすのと 考兊られる。

以上のすべての所見は聴覚機能と棈音作用との間に一 つの共通した閏連つ存在していることを示唂している。 そこであらためて聴覚が構音つある部分を制禦している るつと考えるならば，この回路の Feed-back の障害と なり，長期間に注聴力障害が構音障害堂惹起吼しると むいつらるので,この両者間の関係ば Cybernetics に よつてる説明しらるものと考えた。

6)其声症例

悬腔共鳴沉ついての実験的研究は古くから行われ，19 世紀になつてから音響学的に急速な進歩を逐げている。 我が国炕括いてる1935 年以降日本語鼻音つ音響特性等,

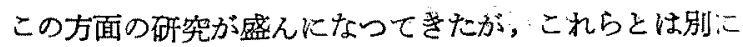
本湎では語音発語明膫度の克場から臨床的に日本語に特 ける鼻声症例を考察してみることにした。

対象としては

i) 開鼻声：麻疩性器罍的開萛声 4 例及び口蓋性器 䓄的闻開鼻声 3 例,

ii) 閉鼻声：前器質的閉鼻声 2 例，と他化正常者住 宜柽及びベロックタンポンを施した1例等である。

まつ麻痺性器貿的開鼻声の初猃時炕括ける語明度值は 45〜54\%，1例のみ 79\%でそれ以外妒中等度言語障害 に該当していたそそれらの発病から初診時までの経過日 数は大略 4〜20病日である.これらの症例はすべて言語

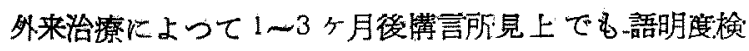

查上に和いてる全治しているのであるが，以上のように 発病時俚大体中等度言語障害保属する程度と考えるこ とができる。

口蓋性器筫的開鼻声の初診時に郝ける 語明度は41〜

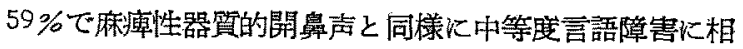
当しており，この軕者間の障害程度については著しい美

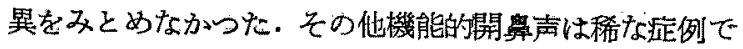

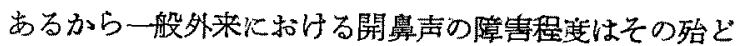
が中等度言語障害つ籍囲に属すると云つてよいと思われ る。

ついで閉覔声については前器筫的閉鼻声の中, 慢性肥

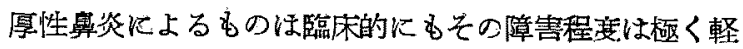
いものであるが，語明度も90\%前後で軽度言語障害代 相当していた.

一方正常者について外鼻孔に水儿浸した䄸橙を施した ときには 99\%で異常聴取される語音は殆どなからた。 また同一被㭘者に対してべロックタンポンを施したとき の同一検者による語明度検查を行うと $94 \%$ であうた。

一般に語明度梌查つ立場から鼻声安観察すると開鼻声 の方が閉禀声よりもその障害程度は強いことが多い．

その他正常者の外鼻孔に綿烃及び罳咽腔にベロックタ ンか゚ンを施してる日常の会話生活には殆ど支障をきたさ ない程度である。

またこの際麻瘏性器質的開鼻声の治療勃果炕ついては 第: 12 表火示すように肺活量計測及び口葐咽頭距離つ改 善化伴つて語明既值の改善むみられる。これ経過判定 の資料になりらるのであるが，この簡単な判定の旁付を 肺活量が演じていることは口蓋裂の項でまた詳述するが 舅味梁い結果であつた。

第 12 表 開舅声の治源效棐

\begin{tabular}{|c|c|c|}
\hline & 症 例 I & 症，例 III \\
\hline & 初診時牧25病日 & 祃診㤼为90病日 \\
\hline 語音発語明䝶度 & $54 \% \quad 92 \%$ & $45 \% \quad 80 \%$ \\
\hline 肺、活量曹通叻法 & $250 \quad 1,200$ & $400 \quad 1,900$ \\
\hline 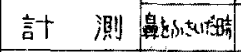 & $1,400,1,400$ & $1,9001,900$ \\
\hline 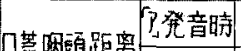 & & $10 \mathrm{~mm} \quad 8 \mathrm{~mm}$ \\
\hline & & $11 \mathrm{~mm} 10 \mathrm{~mm}$ \\
\hline
\end{tabular}

つき開鼻声で障害される語音は「カ」行「方」行， 「夕」行, 「ダ」行, 「タ」行, 「バ」行とこれらの行》

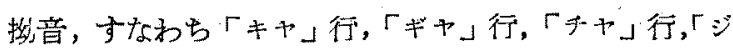
ヤ」行,「ロヤ」行,「ビや」行,「ピヤ」行が最も多く， 「ザ行「バ行も侵されやすいしたぶつて各1，2， 
3 構音域共通つ破裂音たみが主として強く侵され，つい で第2構音域厂摩擦音が障害されやすいという所見であ る.以上要するに各調音点代和ける呼気流の爆発炕対す る障害と解することができて，この疾患の性格を充分て 示しているということができるるのである：

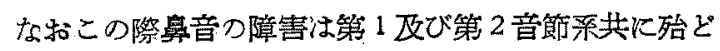
なく，有声子音と無声子音または拐音との間にも障塞つ 差は認められなかつた。

一方文献的に従来から「摩擦音法必然的に強く侵され る」と云われているが，第 2 搮音域の摩祭音を除いてこ れらの結果がみられないのは本検查法の特質からみて， それらが正常発音とは云いえないまです明らかに他の語 音沈きなるらがられる程つ障害程度ではないというこ とのためである。

さらに開鼻声については鼻音すなわち「ナ」行「、」 行とそれらの行の搏音「ニヤ」行，「ミヤ」行が著明に 侵されている・これらの所見から考台せると基声症例 の言語障害つ本䓄は当然各調音点に打ける时気流量の問 題に帰するということが理解でさる。

したがつて麻㾞性器質的開鼻声の治療に際して「らが い小等を反顠させたことが特こ有効であつた事実も当然 の㥠結と教えることができる。なお母音及び半母音は両 鼻声を通じて侵されカが少なかつたのであるが，開鼻声 に批いて注鼻意沘して破裂音が特侵されやすく，閉 䁷声に和いては全くその反対の所見が諗められた。

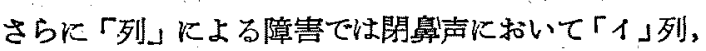
「ウ」列が侵されやすく、「ア」列，「オ」列の障害が少 いという傾向を認めることができた。この理由について は菅原 (1951) は「共辰々幅は鼻音が最大で，母音中で は「ノ」,「ウ」が大きく、「ア゙」は最小で，共振率によ つて更に明砝となり語音間比は之を計数的に示す」と発 表している・すなわわ「ィ」，「ウ」列で活鼻音性が最 す多く、「ア」「ォ」列に括いては鼻音性が少いことの ためである。

一般に後続母音部分て障害は殆どなく, 先行子音の障 苦が主であつて，しか女開鼻声の破裂音に和けるこの障

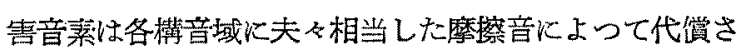

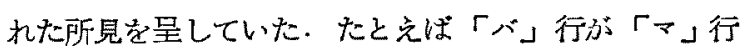
に,「多」行は「ナ」行または「ザ」行に、「夕」行は 「サ」行に，「力」行は「八」行汇，そして「が」行汢 「ナ」行に異常聴取されていたことなどで希るが，これ らは前述の全ての説明に傡付けられた結果であると考え られる。

\section{7) 口蓋 裂}

、蓋裂の言語障害は良来から云われているよ5に閒鼻 声に構音障害の加ううた本疾患特有の 発音を 呈してい る. 口蓋裂成形手術後に括いても往々軟口蓋の後上方へ の挙上, 両側咽頭側索の 隆起, Passavant 隆起の突出 などがなお充分でなく，しか子術前すでに習慣となつて いた解剖的異常を補うための必然的な構音障害が 线つ て依然として特有の異常発音委もたらしていることが多 W.

本項で対象とするのは Scharfe の言語障害程庭によ る分類では第 1，2，3型かいつれか硐するるのであつ たが，この開罘声をさらに手術的に改善しなければなら なからた場合, Shönborn-Rosenthal 法（あるい㤌そ の変法）を施し，その上で発音練習を実揓して言語障 害つ矯正炕努めた・ 口蓋裂成形手術後数々月の各種補功 手段によってす開鼻声つ改善が思わしくなく，その口蓋 咽頭距離が $12 \mathrm{~mm}$ 以上（特飞 $16 \mathrm{~mm}$ 以上飞は高度言 語障害があつた）火大きく，しかす口蓋及び咽頭諸筋つ 協同作用が不充分（特に口蓋唡頭距離がア」発音侍つ移 動 $2 \mathrm{~mm}$ 以下のわの)であると認められたときに，軟口 蓋に対して咽頭後壁から前記の有茎移植升を形成して, 語音発語明膫度上 $26 \%$ の改善をみた症例，あるいは本 手術後 10 病日で語明度值 $82 \%$ ，すなわち軽度言語障害 範囲であつた症例等を 経験し，将来このSchönbørnRosenthal 法つより多くの店用に大きな期待が持てる と考えられたが，今後精確な検討を必要とする分野であ る.

一方構音障害䏓ついては口蓋音が最も強く侵され、っ いで歯音，口唇音の順に軽くなるのが普通である. 発音 練習実施は一般にこの逆の順序で行つたつであるが，有 利な点が多かったと思う。

Scharfe の分類と語明度との関係については， III 節 3) 項つ参照仗よつて大略榆討しうるので，こっでは器 質的な障害程度によってつぎのように分頖し，それらの 各群について考察を加えてみた。

すなわち（第 7 図参照）

第 1 群： 粘膜下口蓋裂 3 例

第 2 群：軟口盖裂 18 例

第3 群: 軟硬口蓋裂 5 例

第 4 唇顎口蓋裂 7 例（片側及び両側共に含 まれる) の計 33 例である.

第 13 表つ上 5 飞第 1 群つ語明度は 47〜 72\%（平均 59 \%), 第 2 群の術前29〜 74\% (平均 48\%)，術後は 33〜 


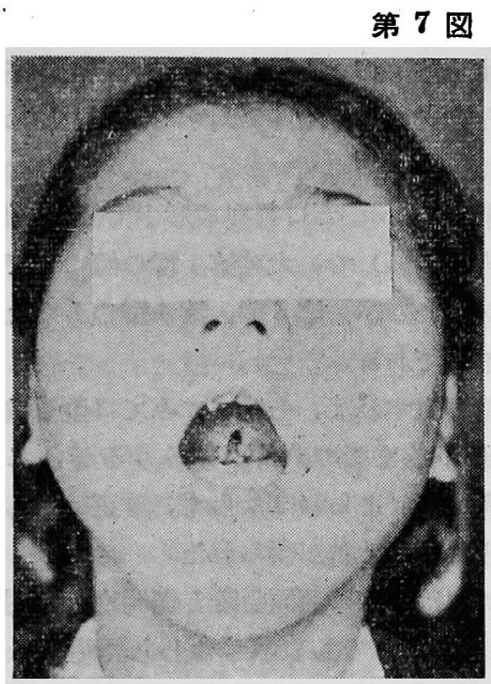

第2 群 21 才乎衍前 (31.12.2 撮影)
蓋

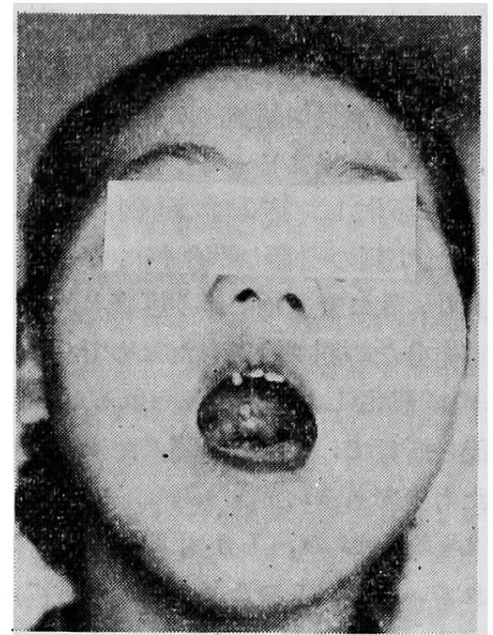

衔 後 (31. 12.24 撮影)

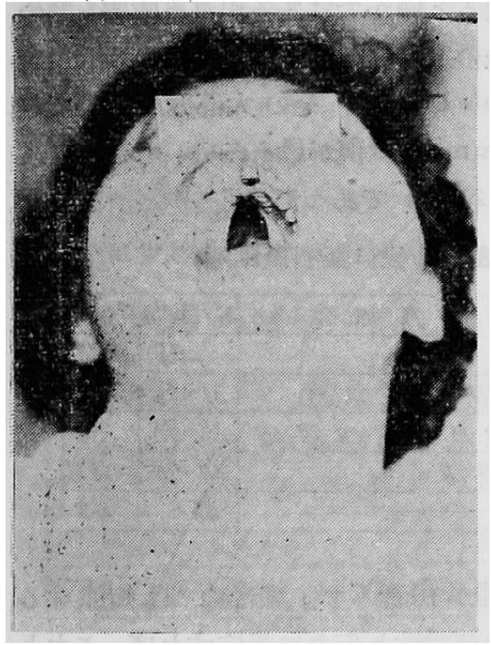

第3 群 21 才 9 行前 (31.5.25 撮影)

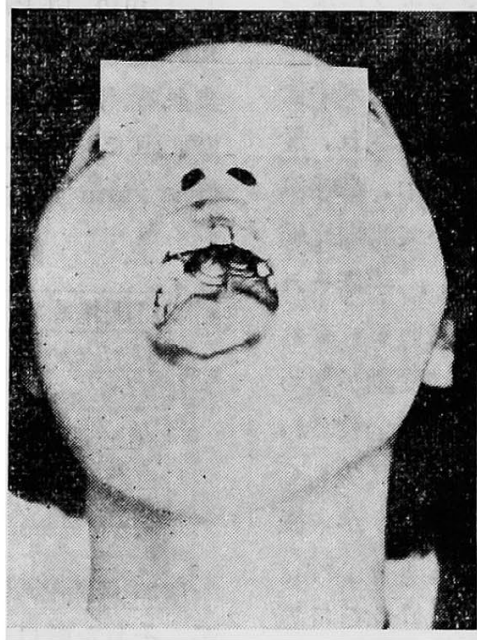

術 後

(31.8. 撮影)

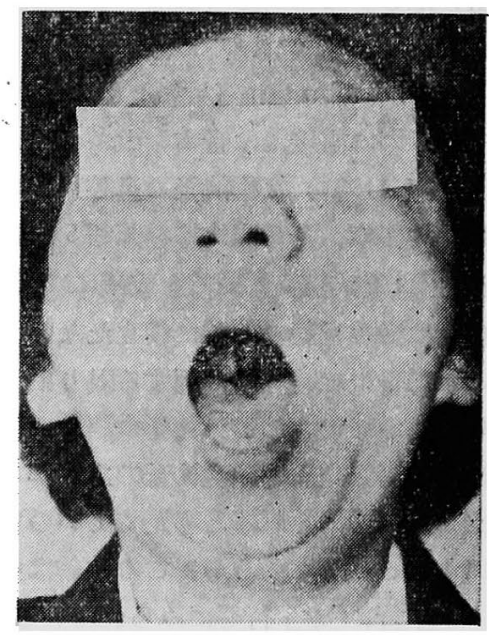

第4 群 24 才 古 衍後 (32. 10. 10 撮影)
第 13 表 口 蓋 裂

\begin{tabular}{|c|c|c|c|c|c|}
\hline & & 語 & 明 度 值 & (\%) & Fins: \\
\hline 机群 & & $47,72,58$ & & & 59 \\
\hline & 微前 & $51,74,55$ & $55,43,53,29,32$, & 38, & 64 \\
\hline 社2群 & 術后 & $60,64,75,48,68655$ & $60,68,43,33,40$ & $41,69.51$ & 56 \\
\hline & 变動 & $+9(-10)+20$ & $+17,+15,+14,+1$ & +3 & +111.3 \\
\hline & 行前 & $20 \quad 37$ & & & 29 \\
\hline & 復后 & $43,31,27,56,35$ & & & 38 \\
\hline 倨 & 術后 & $24,50,76,78,65,4$ & & & 56 \\
\hline
\end{tabular}

$75 \%$ (平均 56\%)，第 3 群つ術前は 20～37\%（平均 29 $\%$ ), 術後は 27〜 56\% (平均 $38 \%$ ), 第 4 群は術前がな く，術後は 24〜78\%（平均56\%）である.

すなわら口蓋裂全般として，その大部分が中等度言語
障害に相当している・しかも第 1 群が最もその障害程度 が軽く,ついで第 2 群，第 3 群つ順となり口蓋裂の程度 に平行している. 第 4 群はいらうれる乳幼児期に既に手術 を施行し，本検查施行時までにその大半が 11 年乃至 27 年経過したものであつて，その間の日常生活あるいは発 音練習による言語の改善が著しく，このために平行関保 がみられないものである.

つぎに術前術後（術後とは発音練習開始前で平均 23 〜24 日目)における語明底の変動, すなわち手術自身に よって言語障害は改善されるか否かという点について㭘 討してみると第13 表にみる通りである．すなわち1〜 $23 \%$ (第: 2 群つ術前後変動刀平均 $11 \%$ ) 程宴、改善がみ 
とめられた。こつうち第 2 群つ+1\%王 $+3 \%$ 殆ど そつ改善が認められなかった例に括いては，前者が術後 13日目で委た経過充分とはい方ず，後者は術挠34日目 ですつたがまだ両側弛張切開創代ガーゼタンポンが插入 されて括り，しかも術後なじめての発音であった。

以上つ他 $10 \%$ 悪化 した策 2 群つ 1 例儿ついては術後 2)日日でいまだ政側の弛張切開創腔にガーゼタンポン が施されてあり，軟口蓋運動に伴う疼痛も残つており，

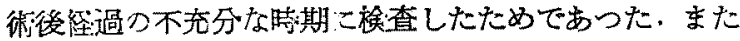
第: 3 君化も $10 \%$ 悪化した 1 例がみられるが，数口蓋粘 膜下注射直後つ所見で，やはり疼痛のため充勞な発音が できなからたものでする。

第 2 群で.よ平均 $11 \%$ の，しかす8例つ全てに術後改 善が認められているが，このことは手耕自身によつて; 一般社会人にとつていまだ正常発音とは云点ないまで る，正しい語音として類推することができるようになつ たと解积できるるのである、この点に関してはStein (1930), Liebmann (1931) その他等によって従来手術 そつわのは直接仙音声を改善せずとして否定され，最 近营原 (1951) は街前後つ鼻腔共鳴の共振々巾, 鼻呼気 量，共振率，語音間比等を邦語 5 母音について測定比較 し、「口蓋破裂手術後でる成績には変化なく, 手衡れれ 自身は音声言語つ改善心役立たない」としている。これ マ5 母音つ鼻腔共鳴に関する限りにおいては変動が誌め られないつであらて, 邦語全語音つ各構音機構全般にわ たつた語音発語明瞭度梌查つ立場からみるならば少しく 改善がみとめられると考元てよいつではなからうか。後 述することではあるが，この改善は主として「カ」行， 「゙」行，「ガ」行等にみられている。したがつて口蕫 筸等に刘する調音点つ対象が，縫合術によつて形成され らといらことなどがこの微少な要因をむたらしているの ではないかと考えられる・しかしながら最近の手術自身 に関する進歩がこの変動をもたらしているのかもしれな い.また一力臨床上「術後発音つ方が少しくわかりよ い」という訴えを，この語明度検查が雴書きしていると

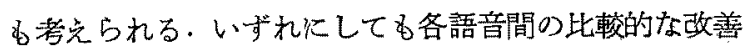
であつて、これを聴賞えいう感覚的な判定によつて把握 する方法であるから，な括今後つ精嘧なる䅹訶を要する ことである。

以上のような文献上の比較は，まず第一下研究方法つ 差異，ついで口蓋裂の程度差，ませはとの手術法つ撰択 そその進步，あるい很前後つ口蓋咽頭諸筋つ状態，咽 頭口蓋距離，さらにその症例自身の言語発育過程とそれ
に対する理解力及び各個人間あるい性語音間における構 音に関する美異等ヶの異つた条件の上になされるるので あるから，自らそつ条件て対する限界を認めね仿ならな い.

第 2 群に叔いては口蓋裂成形手術後つ語明度が 33〜 75\% (平均 56\%) で，大略第! 群の值にむで改善されう ると考克ら机るが，第 3 群，第 4 群つような高度の口盖 裂では不定である。

以上を要約すれば，一般的にみて口蓋裂成形術によっ て語明度 60\% までの改善は望みうるが，これ以上は術 "後の発音練習によらねばならず, 短正いかん炕りり往今 80\%以上までつ改善が得られた。

術後代和ける口蓋咽頭距離と語明度との関保について は第 14 表の通りである.すなわら語明度は、 口蓋㸶頭距 離つみKよつて影響されるるつではないと云える・しか し $11 \mathrm{~mm}$ 以上になると僅かではむるが高度障害も諗め られる・一般に術後つこの距雜は 11〜20 $\mathrm{mm}$ の間に含 まれるものが 19 例中 14 例で，その大部分をしめて机 り, 中でも 16〜20 mm の8例が最も多い. ちなみ㵊 低は $9 \mathrm{~mm}$ 最高は $28 \mathrm{~mm}$ であった。

第 14 表 洐後口䅦咽頍距離

\begin{tabular}{|r|l|r|r|}
\hline$\square$ 咽距离 & \multicolumn{1}{|c|}{ 語 明度 值 $(\%)$} & 铯 回(\%) & 平均( \\
\hline $6 \sim 10 \mathrm{~mm}$ & 48 & 48 & 48 \\
\hline $11 \mathrm{~m} / 5 \mathrm{~mm}$ & $47,40,43,31,56,35$ & $31 \sim 56$ & 42 \\
\hline $16 \sim 20 \mathrm{~mm}$ & $58,60,75,68,41,69,27,65$ & $27 \sim 75$ & 58 \\
\hline $21 \sim 25 \mathrm{~mm}$ & $24,50,78$ & $24 \sim 78$ & 51 \\
\hline $26 \sim 30 \mathrm{~mm}$ & 45 & 45 & 45 \\
\hline
\end{tabular}

な括口蓋咽頭距離が母音「ア」発音诗:儿は短維する が，それを軟口蓋の運動性と仮りに規定すれば、これと 語明度との関係は第 15 表の如くである。すなおら高度 言語障害の3 例はいずれるその運動性が $3 \mathrm{~mm}$ 以下の範

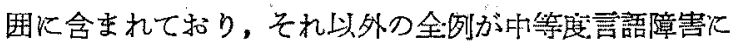
相当し，しかも運動性がますにつれてその語明度す比較 的炕よくなついる. $5 \mathrm{~mm}$ 以上の運動㭫を有する埸合 には、特によい語明度を示している。

第 15 表 衍後軟口琶の運䙲性

\begin{tabular}{|c|c|c|c|}
\hline 運動 性 & 語明度值 & \multicolumn{2}{|c|}{ 䡉团 $(\%)$ 平为 $(\%)$} \\
\hline$a_{m}$ & 27 & 27 & 27 \\
\hline $\ln 2 m m$ & $48,24,65$ & $24 \sim 65$ & 46 \\
\hline $3.4 m m$ & $47,40,41,69,43,31,35,50$ & $31 \sim 69$ & 45 \\
\hline $5 \sim 6 \mathrm{~mm}$ & $68,56,78$ & $56 \sim 78$ & 67 \\
\hline $7 \sim 8 m m$ & 58 & 58 & 58 \\
\hline
\end{tabular}


したがつてロ蓋咽頭距離自身よりる軟口蓋の運動性つ 方が語明度火より大きい影響を及法し5るものと教党ら れる。

口蓋咽頭距離が $12 \mathrm{~mm}$ (伊藤つ計測火上る正常値) 上 上の症例でるとの音声が開放性火鼻音化されることが少 く，殆ぞ正常に近い発音ができるまでに上達することが ある・そこで術後 Gutzmann 式肺活量計によつて肺活 量を訫測する操作をした場合に口上り呼出される空気量 は，第16表の如くに 300 400ceにすぎず他罢孔よ り乎出されてしまう症例は高度言語障害に属し，500:c 以上のものにおいても比較的低い語明度の症例が含まれ ていた. 300〜400cc に相当する語明度に比して $500 \mathrm{cc}$ 以上の？例共その言語障害程变が少く，このロからの呼 気量の多寡がこの附近の值を塄として構音機構に影響を 更恬するのであることが考光られる、この 300〜400cc

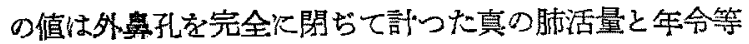
には無関係であるので, 前述の開鼻声の場合と同様與味 梁い所見である.しかも 300〜400cc の間隹根当する症 例数が全 16 例中 9 例 $(56 \%)$ 認められ，200cc 以下は 見られなかつた点，この種疾患の診断と治潦経過つ大略 の推定に少しく役立つるのであった。

第 16 表 蕆腔を開放したまろの肺活量計測

\begin{tabular}{|c|c|c|c|}
\hline 計測値CC & 語 明 度 (\%) & 範团 $(\%)$ & 平均 $(\%)$ \\
\hline $300 \sim 400$ & $\begin{array}{l}40,38,46,43,31 \\
27,56,35,24,\end{array}$ & $24 \sim 56$ & 38 \\
\hline $500 \sim 600$ & 69,65 & $65 \sim 69$ & 67 \\
\hline 700 以上 & $58,50,47,48,78$ & $47 \sim 78$ & 56 \\
\hline
\end{tabular}

つぎに年令化よつて，すなわち日常会活生活の期間犾 長くなるにしたがつて語明度の上景がみられるかどらか について検討してみると，8才以上に括いては殆ど影響 はみとめられなかった。 13 才以下にも20才以上にる高 度言語障害者が同椂に認められている。

上上の他障害語音に関して分析表から観察してみると 各構至域を通じて，その破裂音が最す唚されやすく，つ いで摩繁音である。すなわち、「力」行,「が」行,「タ」

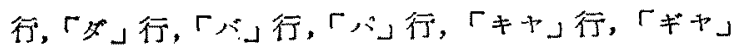
行,「チャ」行,「ビヤ」行, 「と゚ヤ」行, ついで「サ」 行, 「ザ」行,「ヤ」行,「シヤ」行,「ジや行等で, そ れらの構音㦲见よる障害つ程度は本項て前述した通りで あつた.

またこ礼らを代用している語音は本疾患独特つもので
表現し難いものである・な括この疾患で最も侵されがた

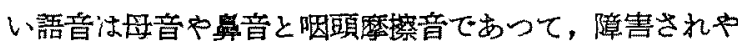
すい語音と共に前項の開鼻声に類似した所見を呈してい た。

な蛙第 1 群, 第 2 群, 策 3 群, 第 4 群见ついて語音障 害つ傾向火著しい差暴は認められなかった。

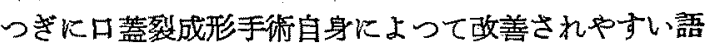
音汇第; 3 構音惐及び第 2 構音惐に括ける破裂音と摩察音 であつて，手術野とこの関係を考号合せるならば，縫合 術つ調音点に及ぼす影響があらためて注目される。

8）片側上顎全摘出泟例

上顎全摘出術をうけた虫者に打いては, 共鳴腔つ変化 による言語障害をおこす。このような症例対して西田 （1953）は母音オシログラムによる術前後の 比較検討を 試みている・しかしいをだ明瞭性つ面からは観察されて いないので，第8図に示すような対象について語明度検 查走行つた，その結果住第17 表の如くである，すなわ ち術後相当の経過によって創腔つガーゼ充罜は除かれる が，この状態でつ 語明度は 全定例が 20〜37\%で高度言

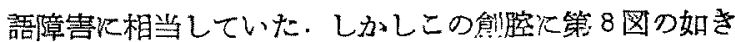
合成膨脂性のProthese を㳖蓎（あるいはガーゼを充 塤した場合には82〜88\%すなわら軽害言語障害にま で改善されていることがかかる。

第 17 表 上額全摘症例の語明度 (\%)

\begin{tabular}{|c|c|c|c|c|c|}
\hline 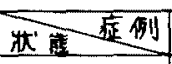 & $I$ & II & III & $\pi$ & 7 \\
\hline $\begin{array}{c}\text { 㓣腔に充埴 } \\
\text { (てない埸合(\%) }\end{array}$ & 27 & 37 & 20 & 25 & 34 \\
\hline 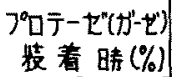 & 88 & 86 & (38) & (82) & 1851 \\
\hline
\end{tabular}

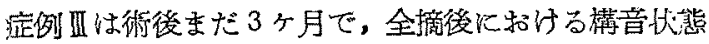
に熟達しうるだけの経過が充分でなく，しかも創腔は

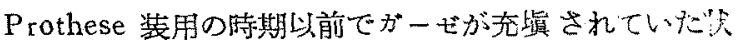
態礼ける語明度であった。

以上つ如く片側上顎全啇出後創腔主閉放したまつに颃

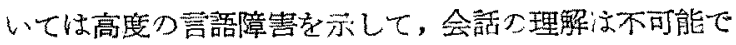

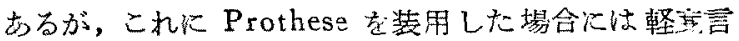
語障害つ程重屯で改善されて，日常会話沈殆ど支障赾 きたさないということになる。

な特年令は 40 才以上70才までであつて，全商施行後

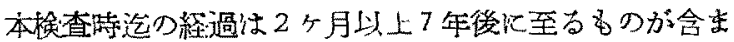
れていた。 
第 8 図上，咢全摘症例

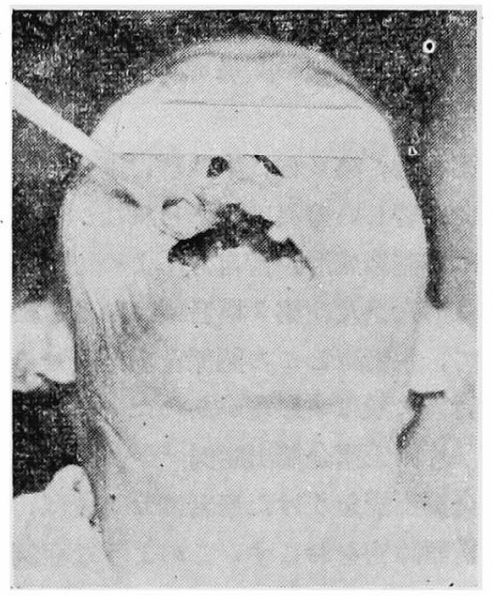

I 49 才 8 (32.8. 3 撮影)
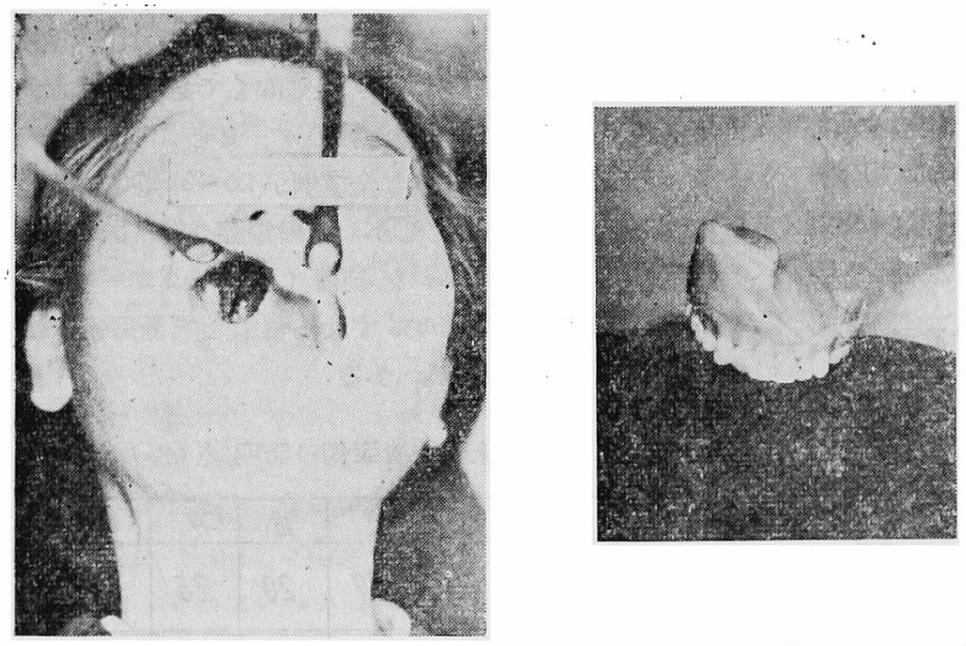

II 55 才 $\odot$ (32.12.7 撮影)

つぎに創腔を開放したま〉の状態にお いて、その言語障害の範囲はどの程度の ものであろうか. 一般にその障害は広範 囲であつて, しか子各語音が異常聴取さ れる程变も強い，すなはち第 18 表の代 表例儿示す如く「行」については「ア」 行, 「八」行とその他「カ」行等が侵さ れ難いが，それ以外つ全行に捺いて高度 に異常聴取された。また「列」について ほ特別の差異がなく，しかも後綕母音部 分の侵された所見も多く見られた. この 結果は構音及び言語の共鳴飞重要な役割 を演じている硬口蓋及び軟口蓋が，その
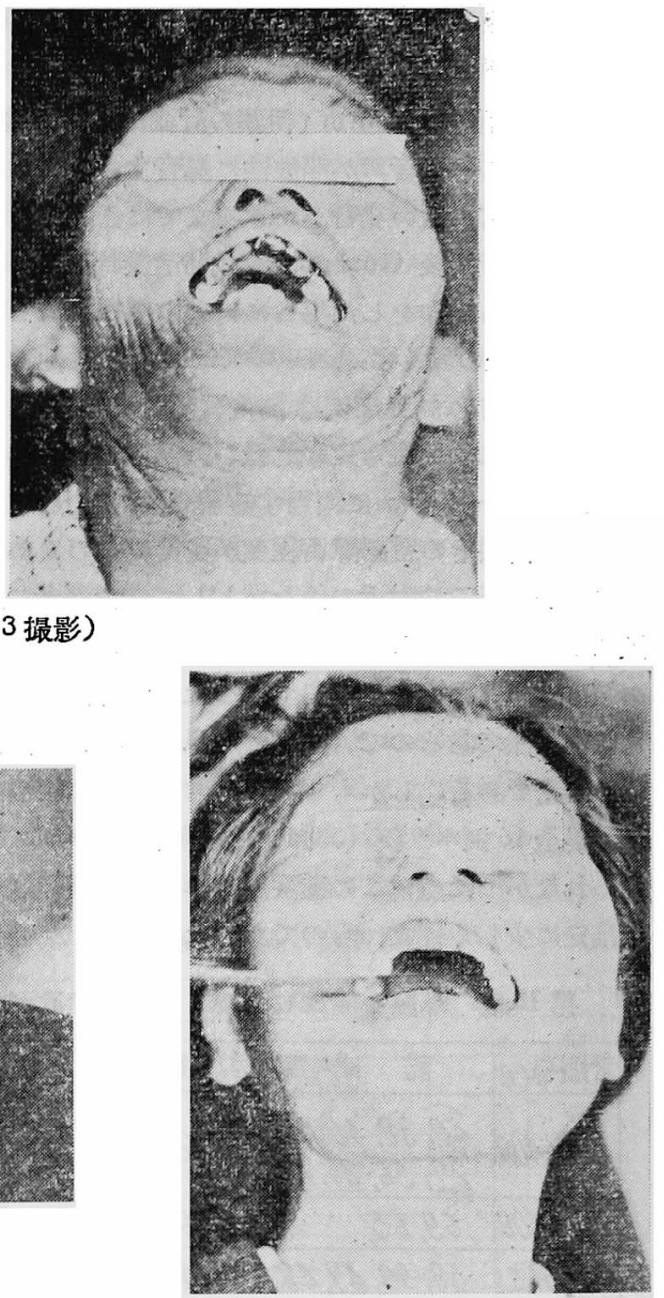

第 18 表 上顎全据站例の分析表

\begin{tabular}{|c|c|c|c|c|c|c|c|c|}
\hline & 70/35 & 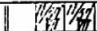 & 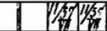 & 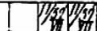 & (3) $397 / 3$ & \multicolumn{3}{|c|}{ 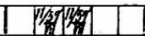 } \\
\hline & 78 & 133 & 3 & $I$ & t & 醇 & 278.882 & $2 \%$ \\
\hline T.K & 力 12 & $\neq L_{L}^{1} 2$ & 7 & 4 & ב & The & $7^{\circ}: 7^{\circ}$ & \\
\hline & サ/4 & 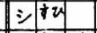 & $z^{3.3 .25}$ & 也按 & 唯 & & 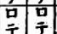 & \\
\hline & $y_{\text {zy }}$ & $4 q^{2}{ }_{2}{ }^{2}$ & \begin{tabular}{|l|l}
3.34 \\
3
\end{tabular} & $\bar{\tau} \hat{u}^{\circ}$ & $1+\frac{6}{4}$ & & $\begin{array}{l}T \\
1\end{array}$ & \\
\hline 尉 & $+\frac{3}{3}$ & $=?$ & 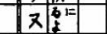 & 齐 & \begin{tabular}{l|l}
1 & 3 \\
\end{tabular} & & 1 & \\
\hline 49 & 八 & $t$ & 74 & $\sqrt{13}$ & 木 & & & \\
\hline & $7^{\pi}$ & 位多: & $A_{\infty}^{\infty}$ & x ho & $E^{3}$ & & & \\
\hline 钐 & $\gg 6$ & & $=23{ }^{3}$ & & $\exists$ कक & & & \\
\hline 歫 & 5.2 & 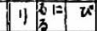 & 13 & $L n^{n}$ & \begin{tabular}{|l|l|l|l}
$x^{2}$ \\
\end{tabular} & & & \\
\hline 0 & मৈ & 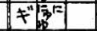 & $7^{*}$ & भ゙ & $3^{\circ}$ & & & \\
\hline & 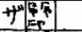 & 㳻点口 & $\left.\pi^{2}\right\}^{3}$ & $\mathrm{t}^{n+z_{3}+4}$ & v"l & & & \\
\hline & 8-5 & & & $\bar{T}^{2}$ 危 & Fै कूर & & & \\
\hline 乵 & バ? & $t^{n}\left[\begin{array}{l}31=7 \\
4\end{array}\right.$ & 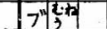 & 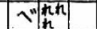 & 村敃 & & & \\
\hline & 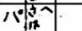 & 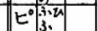 & 70 & $n^{4}$ & 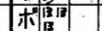 & & & \\
\hline & 7 & & & $x_{\sqrt{3}} z^{5}$ & 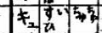 & & 5 & \\
\hline & $3 \%$ & $\because=24$ & $\frac{1}{3} 4^{\text {i2 }}$ & 4 & 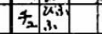 & $f_{3}$ & $\begin{array}{l}52 \\
4 \\
4\end{array}$ & \\
\hline & $\bar{F}$ & $1=13$ & $=$ & $5^{\circ}=$ & $E_{2} 9 \overline{9}$ & & 政 & \\
\hline & 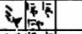 & $\Sigma_{2}$ & $\left.s_{3} b^{n}\right]^{2}$ & $47 \mathbb{F}^{57}$ & 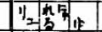 & & 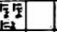 & \\
\hline & 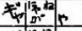 & $\neq=17^{\prime}$ & $\neq \underbrace{}_{3}$ & 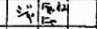 & 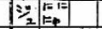 & & 52 & \\
\hline & 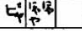 & Ev" & 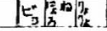 & $\mid \frac{4 x}{4 x}$ & 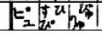 & $t$ & 要 & \\
\hline
\end{tabular}


半側全部あるいは一部分を手術的に除去されることから 思考すれば当然のことである。

な特創檫疓 Prothese を装着，またわがーぜを充填 しても障害されている語音が残るわけであるが，この状 態については「行」，「列」についてあるいはその音節 系について特定の傾向が想められなかつた。

\section{9）声、帯 潞}

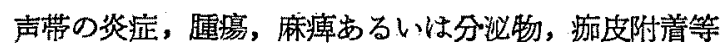
の病的な变化による種々の程度の夏声の場合の語明度を 調查した.この状熊は本来の意味での言語あるいは構音 の障害分野に属するすのではないが，この問題を考察す ることは本疾患がその社会生活に少なから欧影響を及ぼ す点から，その検索もあなから無意味なことではない。 さらにまた次の項で取り扱つた代用音声と種々比軖考察 する上にる與味梁いと考兄られる。

声带癌の臨床に関しては今日まで幾多の研究が発表さ れてきたが，このような閴についての業㺓はきわめて 少い。すなわら切替, 永野 (1957) が本疾患のラジウム 治療後の音声に関して，始めて「会話時の語音は全例を 通じて比較的明瞭でありたとえば電話の不可能なるの は1例るない状況である.」と結論しているにとゔま る.

本項炑いては1 側声带の一部非局したもの, 全長 にわたつたものないしは声帯をこえて更に仮声带また

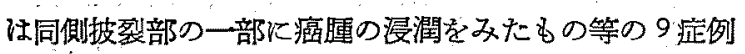

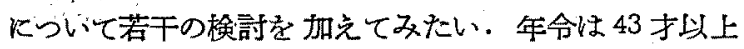
77 才に至る男子 8 例，女子 1 例，嗄声出現以後に和け る絟過期間は 7 ケ以上 7 年 9 ケ月（第 19 美参昭）であ つて，その間シジゥム照射 (Harmar 氏変法（塚本氏 法)」な゙の適当な治療をうけている。

\begin{tabular}{|c|c|c|c|c|c|c|c|c|c|}
\hline 症例 & $I$ & II & $\mathbb{I I I}$ & $W$ & $V$ & $\pi$ & VII & $\nabla r$ & $7 X$ \\
\hline 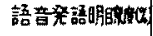 & 78 & 88 & 97 & 68 & 69 & 91 & 79 & 98 & 89 \\
\hline
\end{tabular}

まづ第 1 にこれらの 語明度は第 19 表にみるごとく 68 〜98\%で軽度言語障害て相当していた．この種疾愚は その声量が不足になりやすいので，嗄声のみによる語明 度はさらにこれよりも軽度の範囲にあるといわねね゙なら ない、したがつてその障害はあくまです狭義つ言語障害 に関䋆しないものであつて，しかもその語音つ明膫性に ついては容易に理解できる程度のものである.この絬果 は前述した切替, 永野 (1951) の主張と全く一致するむ
のであつた.

またこの際嗄声は声帯の変形が著しくなる程大体にお。 いて強くなるのが普通であるが，これらの症例火みられ た声帯変形の程度と語明度との関保は必ずしる平行して は怙らずな特今後つ検討にまつべきことである・しか しながら症例 $I V ， \nabla ， の$ 如く軽度と中等度言語障害の境 にあるような場合は少しく声带の变形も高度であつた。

な和後続母音要素の異常聴取は殆どみとめられない程 度の障害であつた。

10）喉頭全摘出症例

啒頭の悪性連湢が原因でその全摘出手術が施された場 合の代償声音儿関する 医学的研究は Czermak (1859). 以来多数発表されているが，これらの明膫性に刘する客 觬的観察はいまだ不完全である。

そこで本項では便宜上以下のような分類について考 察することつした。な机堠頭全摘出手術々式い全例共 Gluck-Sörensen 氏法あるいは Crowe 氏法によるる のである.

i）無喉頭音声

a）食道音声 5 例，b）哂頭音声 5 例，c）口腔仮声 4 例.

ii）人工喉頭法 6例

レントゲン透視法によつて無堠頭音声には種々それら の移行型や混合型が勿論及とめられたのであるが，文れ らの発声機構に打ける主な代償声門の在り場所火よって 以上の如く分類されたものである。なお人脆頭はタビ ア式のもので，現在我が国に执いて一般に用いられてい る第 25 表儿示すような永島軗改良型及びそれらの一部 分を種々患者自身によつて变形されたもの等である。

症例は 38 才から68才までの女子 2 名を含む20例で ある.これらの㙏頭全摘出手術後，本梌查を施行するま での経過期間は第 $20 ， 21 ， 22 ， 23$ 表に示す通りで最少 10 ケ月最高 7 年 6 ケ月の間である。な括これら症例の代用 音声の練習開始時期は大略術後 30 日目頃であるが，最 も早い症例では 3 週間後というものるみられた。 その上 達も人により区々であるが，大体家人にその会話が理解 できるようになるのは早い人で練習開始後約 2 週間位で あつた・

また会話時における声音の大ささは騒音計のマイクロ フォンと被検者の口との距離を約 $50 \mathrm{~cm}$ として测定し た結果，大略食道音声 75phone，咽頭音声が 63phone 附

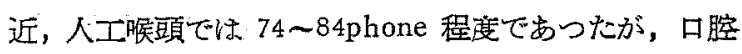
仮声では全般的に非常に小さからた. 
まずこれらつ語明既についてみると食道音声では第20 表つ如く 49 70\% (平均63\%)であり $49 \%$ の1例幏 庭内に括いて生業を営みうるため，会話に特火不自由を きたさず，より上達しようとする努力に不げていたもの で，その他でば63以上70\% た相当している。

第 20 表 食 道 章 声

\begin{tabular}{|c|c|c|c|c|c|}
\hline 例 & $I$ & II & III & $\pi$ & $\bar{T}$ \\
\hline 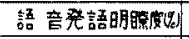 & 70 & 49 & 64 & 63 & 70 \\
\hline 柯后経過期间 & 2 年妍月 & 37 $/ 7$ 月 & 6年57月 & 2 年5n & 746 \\
\hline
\end{tabular}

咽頭音声では 35〜67\% (平均 54\%) (第:21 表), 口腔 仮声で注全例共 30\% 以下（平均 24\%）（第22 表）であ つた. しかし咽頭音声の $35 \%$ の 1 例については，自身 指導的地位にあるため日常殆ど音量つ豊かな人工啹頭を 用いており，咽頭音声は二载的に用いていたものであっ 筮。

第 21 表 咽 頭 音 声

\begin{tabular}{|c|c|c|c|c|c|}
\hline 例 & VI & VII & VIII & $\pi$ & $\pi$ \\
\hline 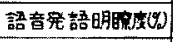 & 35 & 67 & 55 & 66 & 49 \\
\hline 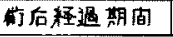 & 5 年5, 月 & 4447月 & 4 年 & 3年 & 2437月 \\
\hline
\end{tabular}

第 22 表 口 膑 仮 声

\begin{tabular}{|c|c|c|c|c|}
\hline 痤 & $\pi$ & $x \|$ & XII & 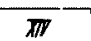 \\
\hline 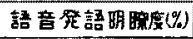 & 28 & 18 & 30 & 18 \\
\hline 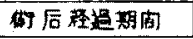 & 3年65月 & 4 47 47月 & 7年25月 & 2447 月 \\
\hline
\end{tabular}

人工䟖頭法症例に扣いては第 23 表に示す如く 29〜73 \% (平均 $51 \%$ ) 汇属している. $29 \%$ の例は人工晈頭法 による会話の機会は日常殆どなく，専ら外出時は筆談を 用いていた例であつて，その使用法に慣れていなからた

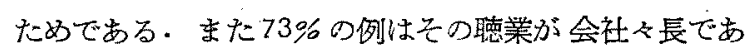
つて，その会話時間も多く，しかも会話挍術と大きな声 量を要求されるために，自ら種々考案工夫を試み，この 使用法に熟達していたつめである。

第 23 表人工恠㙂 法

\begin{tabular}{|c|c|c|c|c|c|c|}
\hline 症 例 & XV & $X 7$ & $X 7$ & XWII & $\overline{X I X}$ & $\pi$ \\
\hline 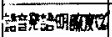 & 55 & 73 & 55 & 50 & 29 & 43 \\
\hline 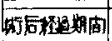 & 5 年 25 月 & 4年2々月 & 105 月 & 105月 & 4 年4 4 & $2445 月$ \\
\hline
\end{tabular}

以上要するに音量つみの点では人工堠頭，食道音声， 咽頭音声，口腔仮声の順序で減少するが，明膫性つ立埸 からみるならば，食道音声が他つ型に比して最も摄れて いる・ついで咽頭音声，人工喉頭がよく口腔仮声におい ては全て高度言語障害に相当して和り，しかるその音量 む極めて小さく言葉つ理解ろ゙不可能である・したがつて
現在多くの学者价つて推摇されている食道音声は。こ

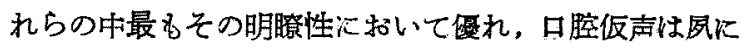
H. Stern (1924) が指摘している如く代償声音として不 適である。

それらの要因としては主に代償声門などの位置的関俰 による構音器官及び共鳴腔の利用範囲の大小，各調音点 に扣ける呼気圧の大小, 乃至は音量, 音の高さを随意に

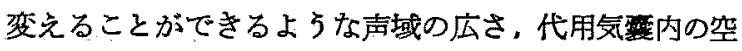
気量の多夏及びその空気乱費の大小とその発声持綕時間 の大小，あるいは有響性の問題やこれら全般に伴う雑音 の大小等をを挙げることができる。

特に人工喉頭においては呼気圧を異常に上界させると 発音函のゴム膜の振動が停止すること等, 性能上の限界 があつて 軽底言語障害即ち語明度 $71 \%$ 以上飞は仲々欧 善し難いものである・第 24 表に示したように手術後 2 年乃至 3 年から語明度検查法を応用し，その結果それら の異常聴取音を指摘しながら練習させ，更にその後1〜 2 年間の経過を本法によって追求してみたが, その間に 殆ど著明な政善を認めなかつた二症例を経験している， このことは人工喉頭法習得にはある时期までは急速に上 達し，それ以上の改善は人工咲頭の性能の限界によつて 非常に困難であるということを示唆しているものと考え る.しかもこの二症例が社会的には特に有能者であり， なおこの聴業及び地位を維持するため照命に人工喉頭 による会話法の習得に専念していたこと等からみると， 中等度言語障害つ上界附近が人工喉頭の機能限界である とい〉うるであるう。

第 24 表 人工嶆頭法による症例の経過

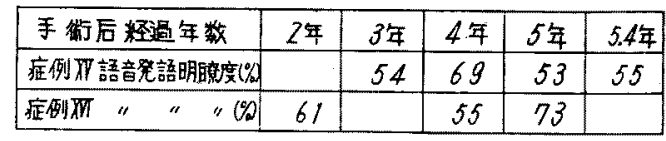

第 25 表人工喉頭計測值 $(\mathrm{cm})$

\begin{tabular}{|c|c|c|c|c|c|c|c|c|c|c|}
\hline$\left.\right|^{\text {人 部 }}$ & 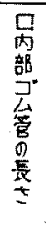 & 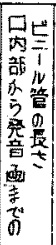 & 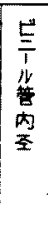 & 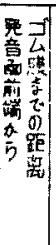 & 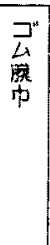 & 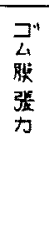 & 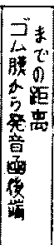 & 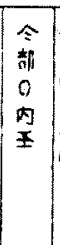 & 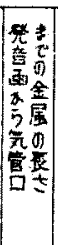 & $\begin{array}{l}\text { 金 } \\
\text { 垔 } \\
\text { 蓝 } \\
\text { 至 }\end{array}$ \\
\hline$N 0.1$ & 4.5 & 12.3 & 0.6 & 10 & 1.0 & $(+)$ & 2.7 & 2.0 & 4.5 & 0.7 \\
\hline 10.5 & 3.4 & 2.8 & 0.6 & 1.0 & 0.6 & $(-)$ & 1.9 & $20 \times 10$ & 0.6 & 270 \\
\hline$\delta .1$ & 5.0 & 14.0 & 0.6 & 1.0 & 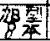 & & 2.0 & 1.95 & 2.7 & 0.6 \\
\hline
\end{tabular}

さらに人工咲頭そのもの小機能的㢳異について考察す るため傫習開始後 1 年， 4 年万至 5 年经過してこっ 
使用法に熟達した 3 名の被梌者に夫ふ第 25 義のよ5な タピヤ式の代表的变形改良型 3 種類についての明瞭度を゙

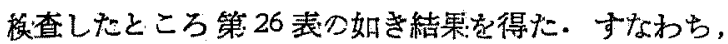
これら3種類の人工堠頍において明睹度は著しく変らな い. 只73\%を示している1 例は前述した人工㬋頭法に 最む熹達したものであつて，これ洛人工㬋頭自身の機

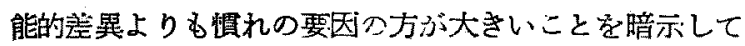
いる乌のと思われる。

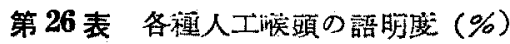

\begin{tabular}{|c|c|c|c|c|c|c|c|}
\hline 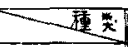 & $\delta A$ 式 & SI式 & YO式 & NO.I & NO. 5 & 8.1 & 平均 \\
\hline 位例 XV & 55 & & & 63 & 47 & 68 & 58 \\
\hline 佂例 & & 73 & & 60 & 64 & 64 & 65 \\
\hline 症 列 视 & & & 55 & 60 & 48 & 44 & 52 \\
\hline 平成 & 55 & 73 & 55 & 61 & 53 & 59 & 58 \\
\hline
\end{tabular}

一方これら代用音声の障害音はいかなる「行」に現わ れるがついて集計してみると第 27 表の如である.す

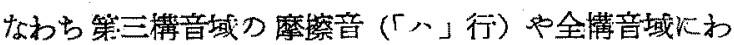
たる破裂音（「パ」行，「タ」行，「カ」行，「ダ」行，「が」

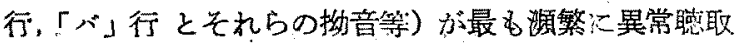
されやすいこと节示している。

第 27 表 障 雷、語 曋

\begin{tabular}{|c|c|c|}
\hline & 最方阵赛されやすい行， & 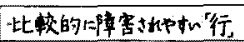 \\
\hline 金连吉声 & 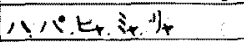 & 9.ナ.ラ.ナ゙キャ。だ \\
\hline 惯竞吉声 & 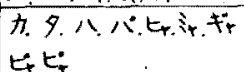 & 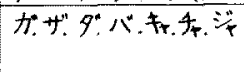 \\
\hline 口住卸卢 & 殆上”全行 & \\
\hline 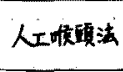 & 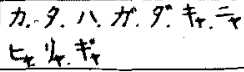 & 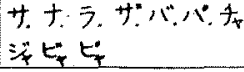 \\
\hline
\end{tabular}

特ここの傾向は人工喉酤法による埸合に強く認められ るが，これ性主としてそれらの棈音に際して調音点に特 ける呼気珐(暴発を起すために必要なたけ)をたかめるた めの性能汇欠けるところがあるためと考光られる・すな わち無椟頭音声に和いては压出空気量が少いこと及び人 工呢謴法においては，呼気流量が限度以上に増すとゴ 膜が却つて振動しなくなるためであるとすれば，合理的 な説明が可能となる・なぜならばこれらの構音障害につ いては元来，棈羔器官の器貿的並びに機能的の著しい、障 害は存在しないはずであるからである・したがつてこれ ら障害語音の爟正はこの機能的限界のためにまことに困 難主さわぬるすのであつて，「八」行等に扣いてい殆ど 不可能といらてすよい程である・

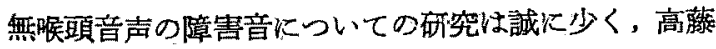
(1953) は「八」行交び $N$ ，NG 等つ急音そD他「ア」
行,「カ」行，「が」行,「ヒ,ブ,プ」等を記載してい 万.

本検查法つ立場が食道音声についてみると「力」行， 「が」行等つ策三構音域つ語音が曼され難いのに反して， その他つ各声音で谈著明に障害されているのは代償声門 の位置的閔係によって，それらの構音に支障をきたすた めであると思われる・な䬤道音声ではその他つものに 比し「サ」行,「㞭」行，「バ」行，「ビヤ」行，「ジヤ」 行,「ピヤ」行つ障害程交が非常に少い。

その他口腔仮声を除いた代用音声に共通してその障害 が少い語音は母暗び半母音と「マ」行，「シャ」行の みである・日腔仮声においては比較的比正常発音に近い と思梳れたのは「サ」行と、「ラ」行つみて，それ以外 の全語音が強く異常聴取されていた。

なお「八」行つ代償性語音について高藤（1953）等は 「ア」行亮報告しているが，䪧者つ症例においてる大部 分が「ア」行であつた。この傾向は人工喉頭法による症 例にも著明に認めら机た。

その他つ代償性晋語としては「パ」行が「バ」行に， 「力」行が「ガ」行火，「タ」行が「合」行火聴さとられ やすい傾向がみられるが，その代表例老食道音声，咽頭 音声，人工呢頭順に第 $28,29 ， 30$ 表としてホした。す なわち同一語音の無声子音と有声子音との間で異常聴取 されやすいよ5な傾向が䍿められているが，この理由る 前述の障帚機序によつて自ら明らかである。

第 28 表 食道音声の語明度分析芸

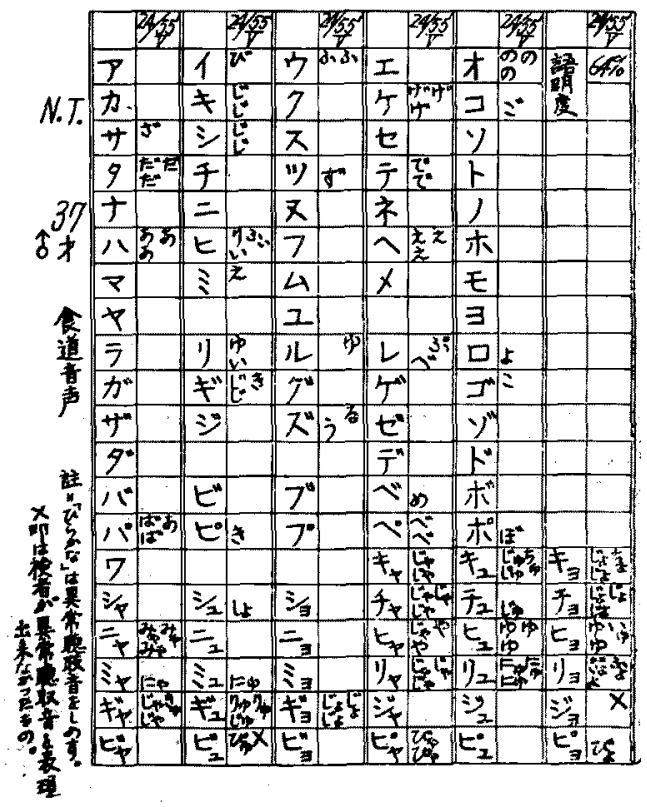




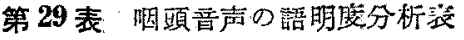

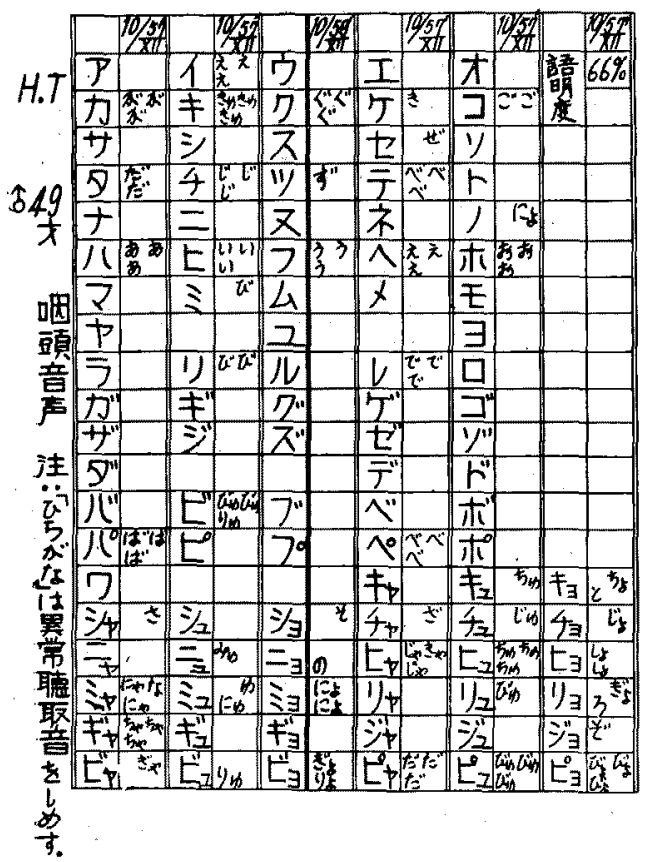

第 30 表 人工啹頭法の語明度分析琶

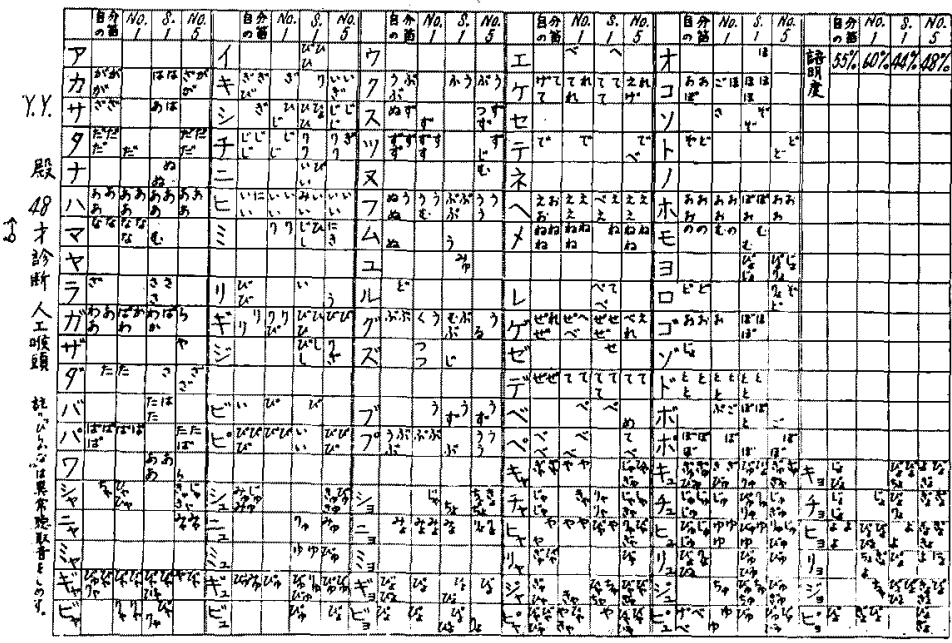

第31.表 口腔仗声の語明度分析表

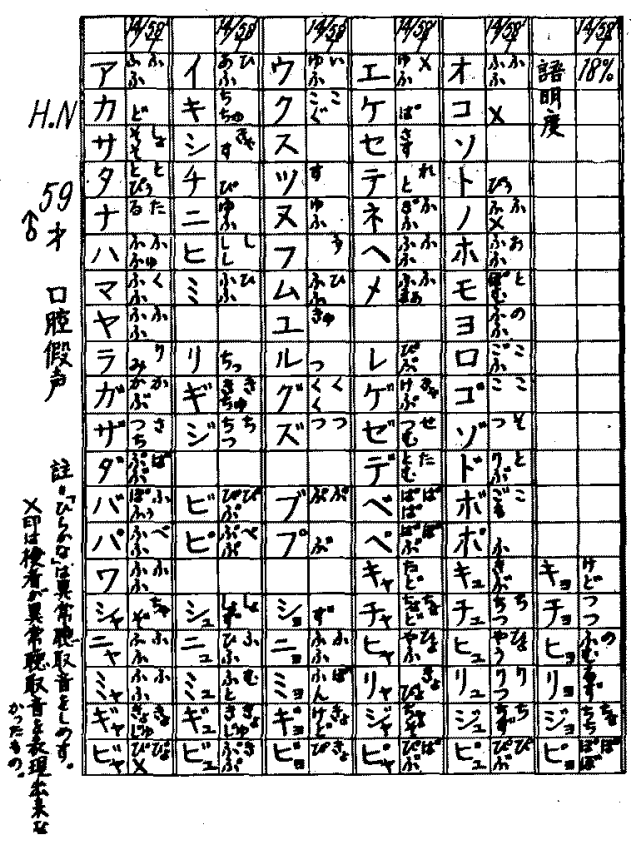

しかしこれらの先行子音に和いてばを の他刀場合と同樣全然無関㑰な子音音 菜として発音されることは少いようで ある。

11）神経系疾虫㲹起因する構語 障害

神経系疾患によつて若き起される言 語障害は口唇, 舌, 口蓋等の言語缼つ 完全麻痺むるいは不完全麻㾇または委 縮乃至 剛直等儿よる 音節性言語障害 Artikulatorische Sprachstörungen と意識運動性 psychomotorisch ある いは五感誌識性 Psychosensorisch のもので大腷皮質の傷害に由来する失 語性言語障害 Aphasische Sprachstörungen とに分類することができる。 後者は内的言語 Innere Sprache の障害で語音発語 明瞭度検查つ対象になり難いつでこの項で愉外するこ とぼた。

前者は外的言語 Äussere Sprache の障害属し通 常延咀值持ける舌下神経, 迷走神経及び副神経等の核障 害，あるいは媨皮貿より前述つ諸核化いたる中枢性层導 路つ障管によつて発現するもので，その程害に応じて構 語障害 Dysarthrie と構語不能 Anarthrie に分ち，ま 
たその性㙺に従心言語煖徐 Bradylalie, 断䋁性言語 Skandierende Sprache, 言語榚跌症 Silbenstolpern, 唡吃 Stammeln, Stottern 等代分類されている。

したがつて臨床上搆語障害は一般に球麻瘏，または脳 出血等による偏㵀つ部分現象としてくる他に，また極め

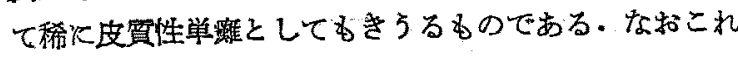
らは両側性つ支配をうけている関係から，両側が侵され ない限り欣第火調節されるおのである。障害語音として は，舌下神経麻㾇のときに舌媈動が障害されて，呂律が 唀らなくなつたり，特に子音の発音が難しくなり，舌 昔を発することが困難または不能となる、同時化顔面神 経つ麻㾇を発するときには唇音るまた発音困難となり。 咽頭迷走神経の麻㾇があれば口腔拉よび声閒の形を適宜 湾化させることが難しくなり，無声あるい、榎声とな り。言語は全く聴きとり難くなる。さらに口蓋麻疸の際 には鼻声がみとめられる等といわれている。

本項で取り扱う刘象は宩大医学部内科及び耳舅咽胒科

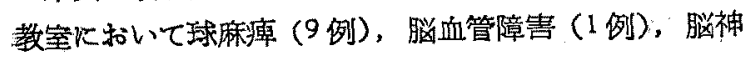
経梅畫 (3例)，脳性麻瘦々の他 (2 例) と診断された 15 症例である・したがつてその年令尿す19才以上 65 才に おたり、その内訳㭷子10名女子5名である・はず第 32表にみられるようにそれらの初診時に敌ける語明度 は15\%から97\%の広範囲炕分散し，脳神経梅毒ではと の経過期間の長短にからわらず共に $80 \%$ 合の軽度言語 障害を示している以外火恪疾患共一定つ傾问が認めら れないとりわけ球麻㾇に执いては15〜97\%で，軽度 から高度までの言語障害が括こりらることを示してい る・しかも大体气の経過期間に平行して扣り，すなわら 4ケ月末满に和いては殆ど正常 (II，IV)，4〜5ケ月では 整度 (III，IVの2回目)，5１4 ケ月では中等度（ $\nabla ，$ VII）とて21 ケ月以上る球庭状が残つている例では高 度 (VI, 吕) と順㳄増悪してゆく傾向を示している・こ

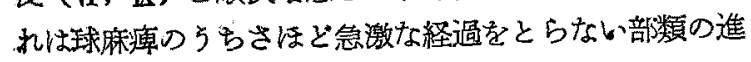
展としては従来一般と云われている型を裹付けしている すのである・したがつてこの種疾患の経過判定の指針と しても本检查法は有意義である。

第32表 棈 音 障 粘

\begin{tabular}{|c|c|c|c|c|c|c|c|c|c|c|c|c|c|c|}
\hline 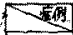 & 7 & II & III & $\pi$ & $\pi$ & III & 7 & $\pi$ & $x$ & $X I$ & XII & 78 & III & $|\pi|$ \\
\hline 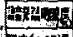 & 87 & 97 & 88 & \begin{tabular}{l|l}
94 & 59 \\
\end{tabular} & \begin{tabular}{l|l}
6932 \\
\end{tabular} & 240 & 63 & 15 & 91 & 87 & 87 & 83 & 93 & 47 \\
\hline 60 & 128 & 35 月 & 5月 & \begin{tabular}{ll|l}
5.58 & 51 \\
\end{tabular} & 5月 21 月 & & & I24月 & 13月 & 4月! & ? & 5 可 & & \\
\hline 时 & & & 球' & 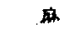 & a & & & & & & & & & Al, \\
\hline
\end{tabular}

つぎに分析表についてみるとある特定つ列について著 明にその匴害を呈するということはないが，「ェい列と
「ニ」の母音部分学伴つた拗音の列が比較的儿多く侵さ

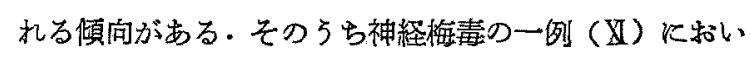
ては第33 表に示与如く「ェ」列の障害を呈していた。 この「列」の発音が少しくこの種矣患にとつて困難であ るということは，これらの言語筋障管の性䁈の一部を示 レているのかもしれない.

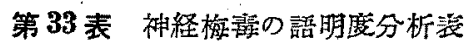

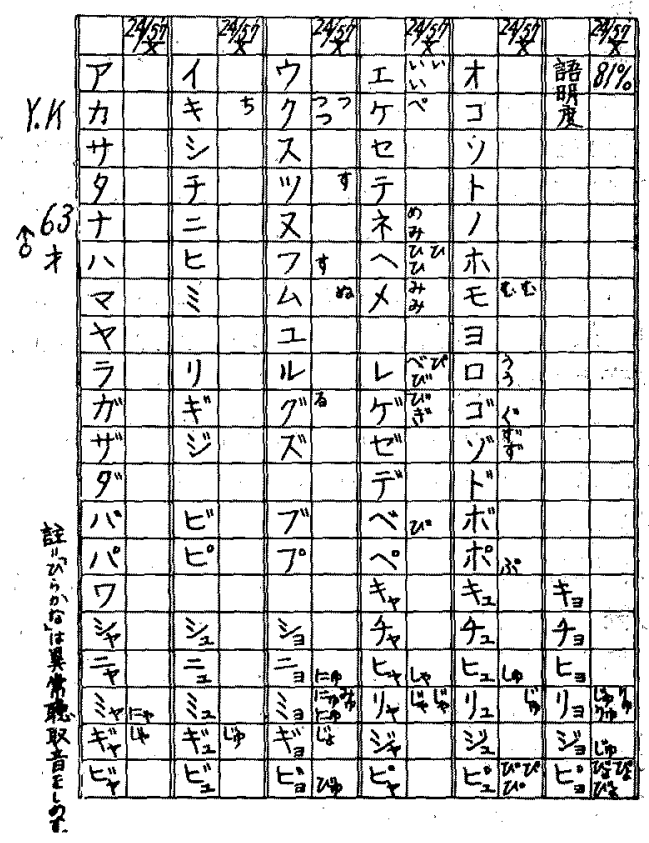

な挌各音節彔による障害の著明な差は認められなかつ たが，舌音と口庴音汅は多くの異常聴取音がみられ，母 音と半母音は比較的に侵されがたかった。

\section{IV・総括並びに結論}

言語障害領域に 対して 新しく「語音発話明蹽度 検查 法」を適用し，始めてこの分野全投に和けるより客鹤的 数值的研究を訊み，つぎの上うな若干の新知見をえたつ でこっに報告した。

1) 本法による検查を 5 人以上とし，言語障害者より 得られた語音発語明瞭屡の最高值と最低值を除外するこ とによって，その語明度值注対する他つ3人の各検查結 果のばらっきを土5\%以下とすることができた。

2）本法火よって各疾患の経過，手術拉よび沿療効果，

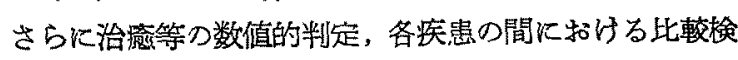
討，障害されている構音域とその構音状熊和よびその代 用語音の影断等々の客観的裹付を得ることがでさた。

3）正常者汇特ける語意発語明䐲度を，臨床的観察及 
び最良語音受聴明瞙交についての 理論等によつて $97 \%$ 以上 $100 \%$ とした。

4) 言語障害全般に対する程变別分類をそれらの臨床

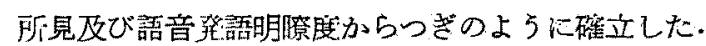

i）軽度言語障慧：71〜96\%，被䖽者の言葉について

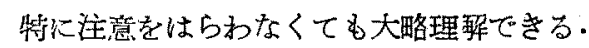

ii）惟等度恶語障書：36〜70\%，充分注意していな いと理解できない。

iii）高纹言語障書：0〜35\%，充分注意していても何 を云つているのか殆ど理解できない。

5）難聴及び神経采疾患儿由来するもつを除いた散発

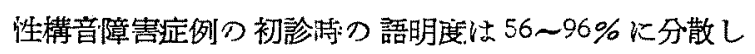
ていた。

6) 構音障害つ語明度分析結果から「ウ」列と「ェ」列 に一連の異常聴取が検出され，また「ナ゙行を「が行 の各語音によつて代用している所見が誌められた・これ らに対して「ウ」列構音障害 (哈) Upsilotismus,「ェ」 列櫵音障謇 (呐) Epsilotismus, 招よび「ナ」行構音障

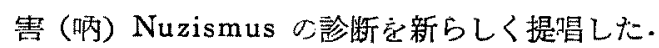

7）耳性㨍音障害において，聴刀障害が言語登育過程 の終了後に発来した埸合つ語明茫は73〜90\%(軽度)， 言語習得前に哦来した症例では 30〜50\% (中等䭒)であ つた・したがらて 難聴発現時:期が、構音障害つ進展に対 しより大きな影響を及ぼするのであると主張した。

8）聴力障害见起因した構音障害症例の 䛊聴語音ある いは自覚誤聴語音と構音障害語音及びそれらの代用語音 との関連性について，種々比較検討を加えた。

9) 聴覚機能と構音作用と開係を Cybernetics 理諭によつてより合理的に考察した。

10) 一般外来診潦で取り扱5開毁声の語明庭は41〜 $59 \%$ (中等这), 閉鼻声では90\% 前後（軽度）のことが 多く，したがつて前者心括いて後者よりもその障害程度 の強いことが，数值的に立証された。

11）開舅声症例火肺活量䄃查を施行した際の外鼻孔か

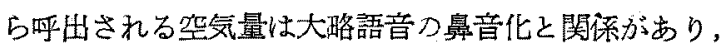
その症状経過の大要を示㖫しうるものであつた。

12）閉鼻声に拈いては「イ」列，「ウ」列にその障書 が強く、「ア」列，「オ」列に比較的に少いという傾向が 藌められた。

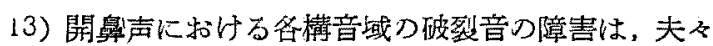
に相当した各構音域つ摩察音によって代用されやすいと いう所見が認められた。

14）粘膜下口蓋裂の語明度は 47〜72\%(平均 $59 \%$ ),
軟口蓋裂の形成手術前は 29〜74\% (平均 48\%)，術後は $33 \sim 75 \%$ (平均 56\%), 軟硬口蓋裂の術前 20 37\% (平 均 $29 \%$ ), 術後俰 $27 \sim 56 \%$ (平均 38\%)，唇顠口蓋裂の 術後は 24〜 78\% (平均 56\%) であうったしたがってロ 蓋裂全般としてはその大半が中等语言語障害に嘅当して

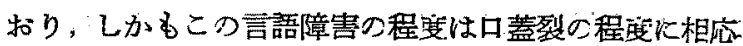
๖ていた。

15）軟及び軟硬口蓋裂の術前術後に和ける語朋度值つ 変動は 10 例中 8 例が $1 〜 23 \% の$ 改善を示したが,軽度言 語障害以上までの改善は主として術後つ発音涷習にまた ねばならなかつた・标手術そのるのによって改善され る語音は主として「力」行，「タ」行，「ャ」行，「力」行 等で日蓋音等つ調音点の刘象が縫合術によつて形成され， るということなどが，この主要因である5と誟た。

16）口蓋裂の成形手術後つ語明宦に対して，口蓋咽頭 距離つ大きさよりる，軟口蓋の連動性つ大小の污がより 强く影響を及ぼしていた。すなわちその運動性が $3 \mathrm{~mm}$ 以下刀場合は語明安要く，5 $\mathrm{mm}$ 以上つときは比較的 によい語明度を示していた。

17）口蓋裂成形術後つ口蓋咽頭距離は著者つ症例では 最低 $9 \mathrm{~mm}$, 最高は $28 \mathrm{~mm}$ であつて，それらつ大部分

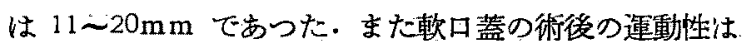
○〜8mm の間にあつて，それらの大部分が $4 \mathrm{~mm}$ 以上 に該当していた。

18）口蓋裂について鼻腔を開放したま〉で肺活量の計 测操作老行了と，年の 16 例中 9 例 (56\%) が 300 400cc を示し，その語明㛺もた 500 に比して低く，しかもこの中に高语言部障霄つ全列が含 まれていた。

19）片側上顎全摘出後澰腔を開放したま1の状態に おける 語明度は20〜37\%(高度) であつたか，これに Protheseを装朋（あるいはガーゼ充古填）した場合に は82〜88\%(軽度)に交で改善された。

20）同椂前者つ開放状態に打いては「ア」行，「八」行 とそつ他「力」行以外つ全行が高度に異常聴取され，ま た後続母音部分つ侵された所見も多く認められた。

21）一側声带に壆腄が限局している状態に和ける語明 逶は68〜98\%(軽度)であつた。

22）無啹頭者における代用音声の語明度は食道音声が $63 \sim 70 \%$ (平均 63\%), 咽影音声 49～67\% (平均 $54 \%$ ), 口腔仮声 18～30\% (平均 24\%), 人工堠頭 43～73\% (平 均 $51 \%$ であつた。したがつて明瞭性の立場からみる と食道音声，咽謴音声，人工喉頭，日腔仮声の順炕わ 
くなり，音量とその音声持続時間等つ観点からみるなら 忙人脆頭が有利である。

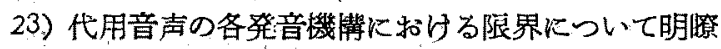
性つ面から娭討を加えたが，これらのらら特こ各調音点 に特ける呼気仕の限界が最も主な要因であることを主張 しなかんつく人工喉頭にこの傾向が著明に現われてい たことを強調した。

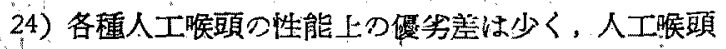
に対する使用者自身の慣れの要因の方が大きいことを指 㹍した。

25）各代用音声の障害語音及びそれらの代償性語音に らくて詳細火明暸度の立場から検討を加え，さらにこ礼 らと各発音機構に拈ける限界との関連性について 諭じ た.

26）脳神経梅毒ではとつ経過期間の長短にかつわらず 80\%台の語明度を示していたが，球麻㾇に和いては 15 て97\%の広範囲に分散していた.

27）さ结ど急激な転㴆をとらない，球麻疩においては， それらの経過期間が長い程低い語明度を示しており，こ の種矤患の経過判定の具体的指針としても有意義である 之思われた。

28）神経系疾患に起因する棈語障害では「土」列と $r=」 の$ 母音部分を伴つた挠音つ列飞比輘的多く侵され やすい傾向を認めた。

\section{文献}

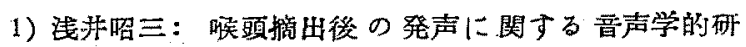
灾，甘耳案，61；1，1958. 2) Arnold, G.E... Audiometrische Untersuchungen bei Stammelfehlern mit besonderer Berücksichtigung der Sigmatismen, Arch. für O.-N. u. K. 150, 1941. 3) Berry, M.F. Eisenson, J.: Esophageal Speech, Speech Disorders Principles and Practices of Therapy. 234 247, 1956. 4) Black, J.W.: Signal reception Intelligibility and Slidetone, Jour, of Sp. and Hexr. Disord. 19, 1954. 5) Barr, B.: Pure tone audiometry for pre-school children, Acta OtoLaryng. Sup. 110, 1954. $\quad$ 6) Bordley, J.E.: The probrem of the pre school child, The Laryngoscope. LXII，1952. 7) 大藤微三：口盐破裂手沺後の

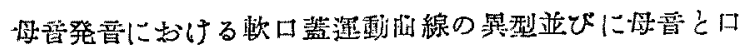

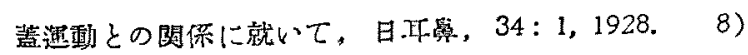
大藤敏三:「パラトグラフィー』について，日耳孯，33； 1, 1927。9）大藤敏三：「バラドラフイー」乱線供

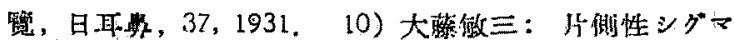
チスムスについて，耳埃，4，1931. 11) Denker, A.

u. Kahler, D.: Handbuch der H.-N.-O. 5; 5, 1929. 12) Fairhanks, G.: A theory of the speech mechanism as a servosystem, Jour. of Sp. and Hear. Disord. 19，1954. 13）後蒺，小林：食道声の成立過

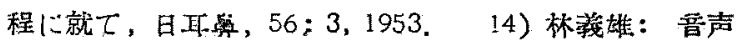

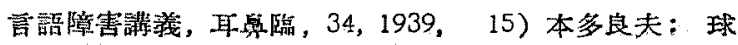

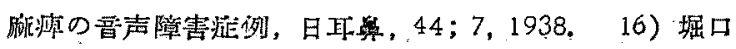

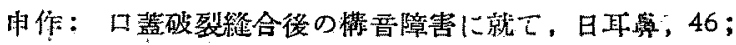

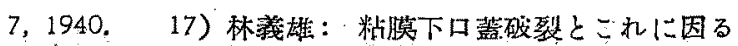

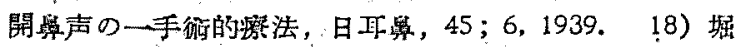

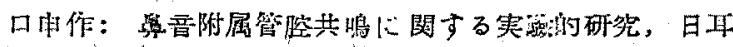
留，49；6，1943.19）浜口一郎：內科診断学，吖風 堂, 1946.20) 橋本進吉：国語学概論；岩波書店，

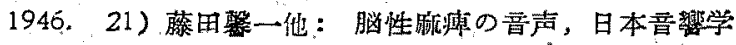
会論文集，5，1956，22）降矢宜成，藤田慗一：「イ」

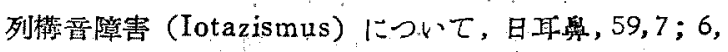
1956. 23) 伊藤，小西：野外における音声伝澾明暸要

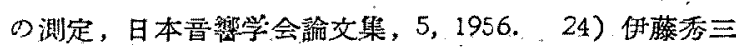
期他：双生完の畐声に関与る研究，日音警諭交集，11， 1957. 25) 石黑您本: 音声学通諭, 広交堂, 1944.

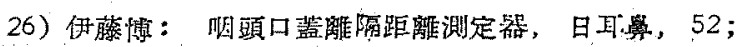
2. 1949. 26') 伊藤搏: Multiple Interdentalität,

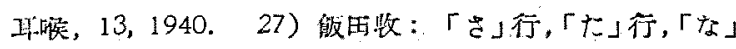
行，「与」行発意障害の1例，耳聅，20；4,1948，28） Jellinek, A.: Amusia ( $\mathrm{On}$ the phenomenology and investigation of central disorders of the musical functions), Folia phoniatrica. 3; 8, 1956. 29）吳促，坂本恒雄：闪科書（上）神経系蜘患，南山 堂，1948. 30) 近藤忠雄：医学統計の手引，日本医学

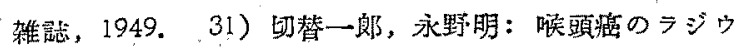

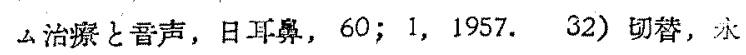
野：声帶癌のシジウム治潜々音声，癌の臨床，2；4,

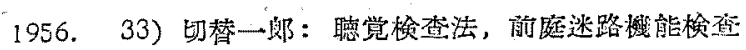
法，医学書院，1951. 34）久保正雄：汛発性吸，正. 䧑, 36, 1941. 35) Koepp-Baker, Ph. D.: Speech problems of the person with cleft palate and cleft lip, Handbook of speech pathology. 597 606, 1957.

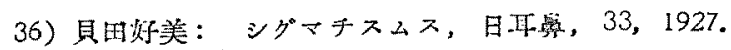
37）宫崎，今井：暴常臮声聴取マトリックスに就て,

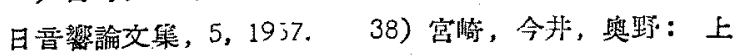

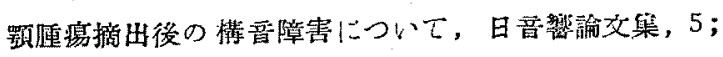




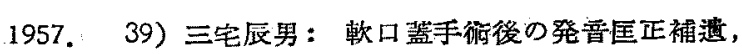
耳喉科，4；1，1931.40) 三宅原男：耳性「シグマテ スムス」について，日耳舅，39，1933，41）三宅展男： 耳性「シグマチスムス」，日耳莮，40，1934. 42) 三宅 辰男：「カッパチスムス」特にその「バラトグラム」に 2いて, 日耳, 40, 1934. 43) Moses, P.J.: The Voice of Neurosis, N. York. Grune and Stratton inc. 1954. 44) 西田練三：偏側上䕱全摘による畐声

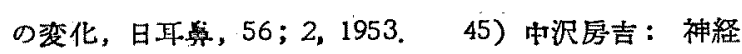
䓋学，日本医畫，1948，46）永井，佐藤，佐藤：明

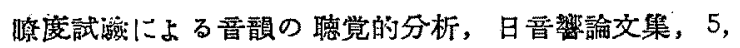
1956. 47) 永井, 佐藤, 岩畸, 吉田：妨害曋声中の邀

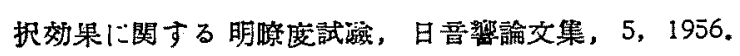

48）日耳算全書，3；1 及び 4；3，1953.４9）西嶋す て：嵩吾部聴打障害による「サ」行昔障害の 5 例，耳 喉，12，1939.50）周本，椿：語普明暸度算出方法に 関する研究, 日耳筧，58；4，1955. 51) 風本, 樯： 語畐明膫度検查用の語䇣に関する研究，日耳悬，57；

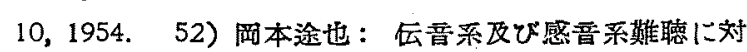
する語昔明睹度検楂とその意義に関する研究，日耳努，

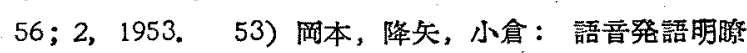
度検查法について，耳喉科，28；1956. 54）大石，杉

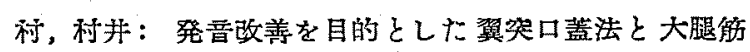
膜口蓋移殖法，日耳算，60；7，1957、55）沖中，高 㭼, 大島: 內科診断学, 学沺書院, 1950. 56) Pete. rson, G.E.: The evaluation of speech signals, Jour. of Speech and Hearing Disorders. 19, 1954. 57) Panconcelli-Calzia, G.: Die Bedingtheit des Lombardschen Versuches in der Stimm-und Sprachheilkunde, Acta oto-Laryng. 45, 1955. 58) Roseinnes, A.: Japanese Reading For Beginners, 1954.

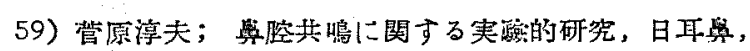
$57 ； 1,1954$. 60) 関, 田口：口䇺魼力と音声学 的諸問趋との関係，日耳算，60；9，1957.61）神保 格：国語昔声学入阴，刀江書院，1940.62）鈴杰䉥

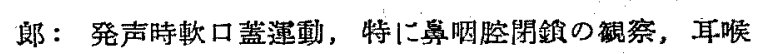

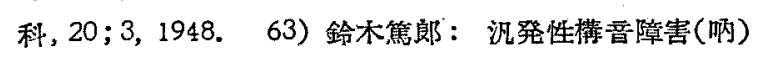

の 1 例, 耳喉, 20；6,1948.64）鉿木篤郎：発声障

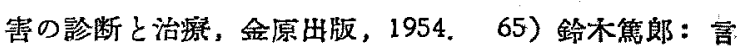
語臫害の診断と治療，日本医書，1952，，66）仙面哲

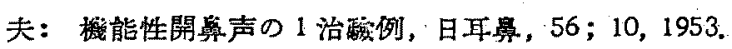
67）堸田，堀口：語音調節上より䘽たる 口琶破裂整形 の諸形式，日耳悬，49；7，1943. 68) 白岩延明：官

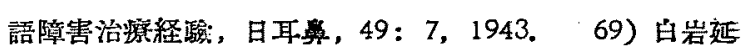
明：學声並に片側性「サ」行構害障害の合併せる 1 例，

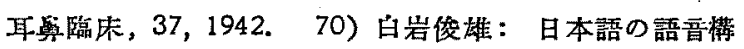
成に関する実閁的研究，日耳点，48，1942，71）豊田

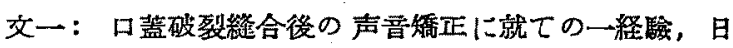
耳鼻，41；8，1935. 72）田中文男：禹展並に口葢破

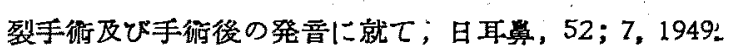

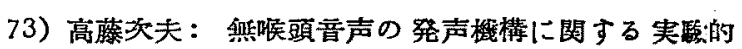
研究, 日耳兽，56；1，1953。74）高藤次夫：無喉頭

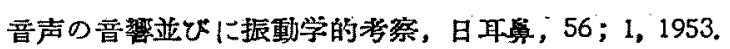

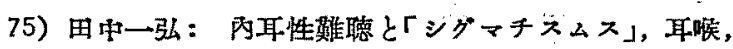
3, 1930. 76) Takahashi, M.: How to speak Japanese language, 1952. 77) Vaccari, O.: Complete course of Japanese conversation grammar, Charles. E. Tuttle Co. 1954.

終りに臨み本研究に入る端緒炎与えら机，長

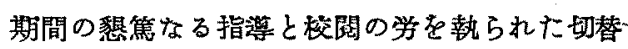
一郎教授に心から拜謝する・なお有益なる助言 と好意を奇さられた凮本途也博士，永野明学士 に,また多大の嗳助を与えられた藤田馨一博 士, 高藤炏夫博士, 松岡哲朗学士, 沢尔修二学: 士に厚く感謝の意き高する。

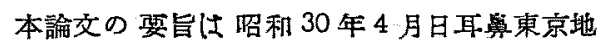
方会第326回例会区び同年 7 月同会第329回例 会，同年10月同会第 27 回大会，同年 11 月日 耳兽関東地方会第332回例会，同 31 年 1 月同

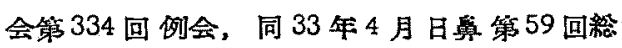
会, 同 33 年 11 月日本晋声言語医学全絰会にお いて発䕍した。

（原稿到臣=昭和 33.9 .22 日一急載） 